The University of Minnesota Agricultural Experiment Station

\title{
Spreading and Adherence of Arsenical Sprays
}

\author{
By William Moore
}

Division of Entomology and Economic Zoology

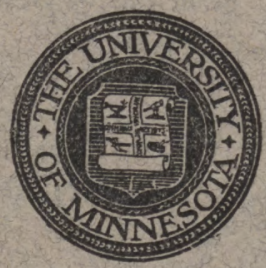




\section{ADMINISTRATIVE OFFICERS}

R. W. Thatcher, M.A., D.Agr., Director

ANDREW Boss, Vice Director

A. D. Wusson, B.S., in Agr., Director of Agricultural Extension and Farmers' Institutes

C. G. Selvig, M.A., Superintendent, Northwest Substation, Crookston

P. E. Miller, B.S.A., Superintendent West Central Substation, Morris

O. I. Bergh, B.S.Agr., Superintendent, North Central Substation, Grand Rapids

M. J. Thompson, M.S., Superintendent, Northeast Substation, Duluth

R. E. Hodgson, B.S. in Agr., Superintendent, Southeast Substation, Waseca

Charles Haralson, Superintendent, Fruit Breeding Farm, Zumbra Heights,

(P. O. Excelsior)

W. H. KENETy, M.S., Superintendent, Forest Experiment Station, Cloquet

W. P. KIRKWOod, B.A., Editor

Alice McFeely, Assistant Editor of Bulletins

Harriet W. Sewall, B.A., Librarian

T. J. HorTon, Photographer

R. A. Gortner, Ph.D., Chief, Division of Agricultural Biochemistry

J. D. Black, Ph.D., Chief, Division of Agricultural Economics

ANDREW Boss, Chief, Division of Agronomy and Farm Management

W. H. Peters, M.Agr., Acting Chief, Division of Animal Husbandry

Francis Jager, Chief, Division of Bee Culture

C. H. ECKLes, M.S., Chief, Division of Dairy Husbandry

W. A. RILey, Ph.D., Chief, Division of Entomology and Economic Zoology

Wrllam Boss, Chief, Division of Farm Engineering

E. G. Cheyney, B.A., Chief, Division of Forestry

W. H. Alderman, B.S.A., Chief, Division of Horticulture

E. M. Freeman, Ph.D., Chief, Division of Plant Pathology and Botany

A. C. Smrth, B.S., Chief, Division of Poultry Husbandry

F. J. Alway, Ph.D., Chief, Division of Soils

C. P. FrTCH, M.S., D.V.M., Chief, Division of Veterinary Medicine

STAFF OF DIVISION OF ENTOMOLOGY AND ECONOMIC ZOOLOGY

W. A. RILEY, Ph.D., Entomologist and Parasitologist

A. G. Ruggles, M.A. Entomologist

F. L. Washburn, M.A., Economic Zoologist

William Moore, Ph.D., Associate Entomologist, Insecticidal Investigations

R. N. Chapman, Ph.D., Assistant Entomologist, Stored Products Insect Investigations

H. H. KNIGHT, Ph.D., Assistant Entomologist, in Charge of Collections

S. A. Graham, M.F., Research Assistant, Forest Insect Investigations

L. V. France, M.S., in Agr., Research Assistant

W. E. Hofrman, A.B., Research Assistant

Marshali. Hertig, B.S., Assistant in Entomology 
The University of Minnesota Agricultural Experiment Station

\section{Spreading and Adherence of Arsenical Sprays}

By William Moore

Division of Entomology and Economic Zoology

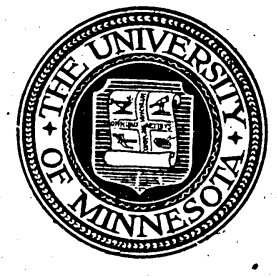




\section{TABLE OF CONTENTS}

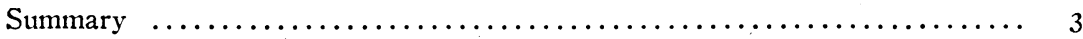

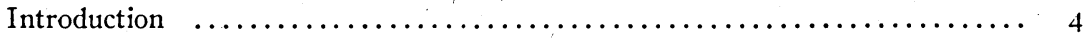

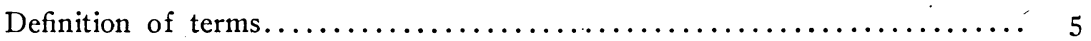

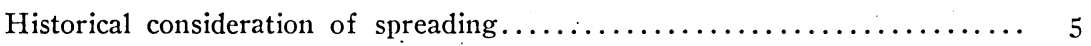

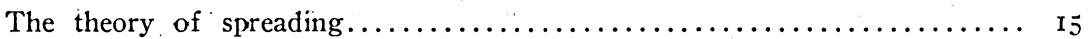

Sprays that will spread on cabbage leaves...................... 18

Sprays that will spread on other leaves........................ 20

Conclusion regarding the phenomenon of spreading.............. 22

Historical consideration of adherence......................... 22

Use of organic materials with fungicides.................. 22

Use of organic materials with insecticides.................. 24

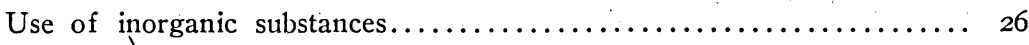

A new theory of adherence.............................. 29

Electric charge exhibited by the common arsenical preparations......... 30

Electric charge exhibited by the leaf surface.................. 3 I

Preparation of an electrically positive arsenical substance............ 32

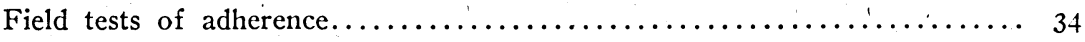

Preparation of positively charged ferric arsenate................. 36

Comparative toxicity of different arsenical preparations.............. 39

Methods of determining comparative toxicity $\ldots \ldots \ldots \ldots \ldots \ldots \ldots \ldots, 40$

- Comparative tests of toxicity............................ $4 \mathrm{I}$

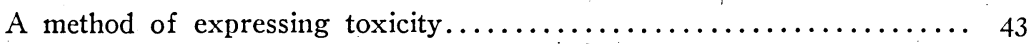

Influence of ferric hydroxide on toxicity ...................... 43

Conclusion regarding the phenomenon of adherence................... 44

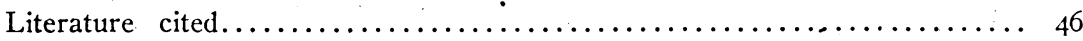




\section{SPREADING AND ADHERENCE OF ARSENICAL SPRAYS}

By William Moore

SUMMARY

The addition of material similar in chemical constitution to the leaf surface causes the spray mixture to form a film of liquid over the leaf.

The positive adsorption of the added material at the leaf-spray interface, resulting in a lowering of the interfacial tension, appears to offer the best explanation of the results.

Different types of leaves naturally require different materials. Thus organic compounds such as beechwood creosote, carvacrol, or amyl alcohol, soluble in fats and waxes and but slightly soluble in water, produce good spreading over waxy leaves, such as cabbage.

Various proteins and plant infusions give good spreading on leaves with surfaces of cellulose, even when they are strongly cutinized, as in the case of plum and citrus leaves.

Suspensions containing small-sized particles adhere better than those with larger particles.

An even distribution of the spray over the leaf tends to increase the adherence.

The leaf surface, when wet, exhibits a negative electric charge.

The common compounds of arsenic, such as lead arsenate, paris green, calcium arsenate, and others, have particles carrying negative electric charges.

Arsenic compounds of aluminum, chromium, and iron may be prepared so that the particles carry a positive charge.

Ferric arsenate appears the most promising and is more toxic than lead arsenate.

Field tests show that electrically positive arsenical preparations adhere more strongly to the leaf surface than do those which are negatively charged.

Ferric oxide, or hydroxide, by adsorbing compounds of arsenic, lower their toxicity to insects.

The ratio of the amount of the arsenic compound in the body to that in the excreta is a better basis of comparing toxicity of different arsenical preparations than tests based on the food consumed or the time required to produce death.

\footnotetext{
1 The writer wishes to acknowledge the assistance of Dr. R. A. Gortner, of the University of Minnesota, on certain phases of the problem, particularly the studies of cataphoresis and endosmosis.
} 


\section{INTRODUCTION}

The successful use of arsenical sprays for the control of various injurious insects depends upon a number of factors. The simple recommendation of paris green or lead arsenate is not sufficient, since the results will vary greatly according to the character of the plant or insect. If the plant is particularly sensitive to arsenic, care must be taken to use an arsenical material with a very low percentage of soluble arsenic. In spraying plants subjected to moist conditions resulting from frequent light rains or fogs, the stability of the arsenical preparation becomes of prime importance. Many compounds of arsenic are decomposed by the action of water and carbon dioxide.

Leaves require a spray mixture of such a character that the film produced at the time of spraying will persist and will not tend to collect in drops and roll off. This is particularly true of waxy leaves, such as those of cabbage, or strongly cutinized leaves, such as those of the cirrus fruits. Such spray mixtures are not only more economical but are also of great importance in the control of insects, which, like the plum curculio, feed on isolated portions of the plant.

Not only the nature of the plant but also that of the insect must be considered. Some insects are easily destroyed by arsenical poisons, while others require large quantities to produce the desired results. When the plant to be treated is not sensitive to soluble arsenic, a resistant insect may be destroyed by the use of a compound containing a rather high percentage of free arsenious oxide, or one which readily decomposes with the liberation of soluble arsenic. In most cases, however, the use of a very stable and insoluble arsenical substance is required. Only a. small percentage of such a poison is absorbed by the alimentary tract of some insects, the major portion being excreted. The excreta in such cases may be white in color owing to the presence of lead arsenate, and chemical analysis will frequently show that more than fifty per cent of the poison consumed was not absorbed. By greatly increasing the quantity of the arsenical material applied to the leaves, the death of such insects may be produced, but such an increase is not always justified from an economic standpoint. Smaller quantities of the poison may be successfully used, providing it remains on the leaves long enough for the insect to consume a killing dose. The adherence of the dried material of the spray, that is, its ability to withstand the washing effect of rain and dew, thus assumes much importance. Plants subject to the attack of an insect over a long period of time must be treated with a very adherent spray, or the treatment must be repeated several times.

The present investigation is a study of the principles governing the uniform distribution of the spray material over the plant, and the adherence of the dried particles when subjected to rain, dew, wind, and other 
influences. The object of the stidy is general, and no effort has been made to apply the results to the control of any particular insect.

\section{DEFINITION OF TERMS}

Many attempts have been made, in the use of insecticides and fungicides, to insure even distribution of the spray over the foliage of the treated plant. In many of the papers dealing with this matter it is not clear whether the investigator is considering the spreading of the spray over the foliage or the adherence of the dry materials. Statements that the spray did not "stick" or adhere well to the plant are frequent. In some cases, from the context, it is apparent that reference is made to spreading, the drops of the spray having failed to adhere to or spread over the leaves. The term "wetting" is frequently used as a synonym of spreading. Throughout this paper the word "spreading" will be used to denote the formation or the maintenance after being formed, of a continuous film over the surface of the leaf, and "adherence" will apply to the resistance to the action of rain, dew, and wind exhibited by the spray material after it dries. The term "wetting" may be considered as the slight.chemical or physical affinity between the liquid and the solid, which is one of the factors in the formation of a continuous film.

\section{HISTORICAL CONSIDERATION OF SPREADING}

One of the earliest records of the use of a material which tends to produce the spreading of a spray over the leaves is contained in the Rapport au Ministre de L' Agriculture (1885). This report deals with the treatment of the mildew of the vine, and Davis; an investigator, is reported to have used 6 kilos of glue to 800 liters of copper sulphate solution, thinking that the glue increased the efficacy of the remedy. Whether the increased value of the spray was caused by a more even spreading or by a better adherence is not mentioned. The following year, Millardet and Davis ( 1885 ) said that the addition of glue to bordeaux did not appear to be of notable advantage.

Soap or soapsuds was early used in contact sprays with tobacco and other materials in order to insure the spreading of the insecticide over the body of the insect. Altho the earliest applications of paris green were in the form of dust, the use of suspensions of paris green or london purple in water soon developed. Gillette (I890) used soapy solutions with paris green and london purple, but found that these mixtures were more injurious than a suspension containing no soap. The addition of flour at the rate of half an ounce to a gallon was tried, but this preparation also proved more injurious. The increased injury, it was thought, was due to the greater adhesiveness of the mixture. Resin in the form of a soap, sodium resinate, was successfully used without increasing the amount of injury to the foliage. Washburn (I89I) used 
whale oil soap, 6 pounds to 50 gallons of a paris green suspension, thereby producing an even spread of the mixture over the fruit and leaves, and apparently rendering the poison more tenacious. Galloway ( I892) used soap with different fungicides to increase spreading. Swingle ( I894) recommended the use of soap with bordeaux mixture. No definite quantity was specified, it was said merely that sufficient soap should be added to give a good permanent foam. This result was usually obtained by using a quantity of soap equal to one half the combined weight of the copper sulphate and lime in the bordeaux mixture. Fairchild ( I 894) used soap with eau celeste, obtaining excellent spreading even on leaves with a heavy cuticle, such as those of the pear. Galloway (I894) used a resin soap with bordeaux mixture, finding it just as effective in producing a continuous film on the leaf as Ivory or whale oil soap. Lowe (1896) encountered considerable difficulty in spreading a lead arsenate spray evenly over the surface of willow leaves. Glue used at the rate of 2 quarts to 45 gallons of spray gave satisfactory results.

The indefiniteness encountered in the use of soap as a spreader for various spray mixtures was shown by the analysis of various soaps by Van Slyke and Urner (I904). They showed that in the different makes of whale oil soap the water content varied from I I.I 5 to 54.85 per cent and the amount of actual soap from 14.90 to 59.27 per cent. The nature of the alkali present varied greatly, as did also the quantity of fatty acids and resins. Other common soaps showed a similar variation. The addition, therefore, of a definite amount of soap to a spray may or may not cause an even distribution of the material over the leaves.

Mausier (1908) studied the spreading of a number of liquids over different solids. He realized that spreading is dependent on the nature of the solid and of the liquid, but considers this difference as due to the surface tension of the liquid. A liquid which will spread over a particular solid must possess a certain definite surface tension value. If it has this value it will spread regardless of the nature of the liquid. A spray containing 30 grams of soap to Io liters of water with either 50 grams of oil of tar or Io grams of formaldehyde is considered as meeting the surface tension requirements of the leaf.

Vermorel and Dantony (I9IO) state that a body is wetted by a liquid, i.e., the liquid spreads over it when the cohesion of the molecules of the liquid, the one for the other, is less than double their adhesion for the solid. They distinguished between the surface tension of a fresh surface of a soap solution, dynamic surface tension, and the surface tension of an old surface, static surface tension, considering tha: there was a direct relationship between the static surface tension of a soap solution and its ability to spread over an insect. Measurements of the surface tensions, by means of a stalagmometer, of several organic compounds' were made, and it was found that none possessed as low a 
surface tension as a soap solution. Since no mention is made of the time allowed for the formation and breaking away of the drop from the tip of the stalagmometer, it is doubtful whether sufficient time was allowed for the concentration of the soap in the surface layer, thus insuring a true measurement of the static surface tension. In a second paper, Vermorel and Dantony (I9II) take up the addition of soap to fungicides to increase their spreading, showing that the results obtained depend largely upon the method used in the preparation of the mixture. A method is mentioned for the preparation of a colloid copper soap which exhibited good spreading properties.

Parker (I9II) found that the addition of 2 or 3 bars of common laundry soap to each 50 gallons of a lead arsenate spray retarded the settling out of the suspended particles. The use of soap with arsenical sprays to retard settling and to increase spreading, when tried under orchard conditions by certain growers, was frequently accompanied by an increased injury to the foliage of the sprayed plants. These results caused Tartar and Bundy (I9I3) to investigate the action of soap on lead arsenate. They showed by chemical analysis that the addition of different soaps had little influence on the neutral lead arsenate $\mathrm{Pb}_{3}\left(\mathrm{AsO}_{4}\right)_{2}$, but that the addition of soap to the acid lead arsenate $\mathrm{PbHAsO}_{4}$, rendered soluble a considerable quantity of the arsenate: Since the acid lead arsenate is more generally used than the neutral, the addition of soàp to cause spreading can not be safely recommended. Edwardes-Ker (19I3) also studied the addition of soap to lead arsena`e sprays, obtaining results opposed to those of Tartar and Bundy. $\mathrm{He}$ found that the addition of I per cent of soap, either home-made or commercial, did not influence the solubility of lead arsenate suspensions. Both home-made lead arsenate, formed by the reaction of lead acetate and sodium arsenate, and commercial lead arsenate were used in the experiment. No distinction is drawn between the different kinds of lead arsenate. The mixtures of lead arsenate and soap were filtered half an hour after being made up, and the arsenic in the filtrate was determined gravimetrically as magnesium pyroarsenate. Tartar and Bundy used less soap, 4.8 grams to I, Oco cubic centimeters of water, but the mixture was allowed to stand six hours before filtering. They used the iodine titration method of Gooch and Browning in the determination of the quantity of soluble arsenic. As the lead arsenate and soap would generally be mixed for periods longer than half an hour, and even after spraying would have an opportunity for chemical reactions, it appears that the restlts of Tartar and Bundy more nearly represent the effect of adding soap to lead arsenate sprays.

Gastine (I9I2) recommended the use of saponin to reduce the surface tension of spray materials and hence to insure spreading. One of its advantages is said to be that, unlike soap, it is not precipitated by acids 
or metallic solutions, and will not cause injury to the plants. Saponin can therefore be added to either fungicides or insecticides without danger of any decomposition resulting. It may be used instead of soap in the formation of emulsions. Used with beechwood creosote or coal-tar creosote the surface tension of the mixture was lower than that of the pure saponin solution.

Weinmann (I9I2) prepared a cupric spray with calcium polysulphide and soap, finding that this combination gave a very high drop number and spread well. The drop number of the cupric spray with soap, but without the polysulphide, was much lower. The substitution of saponin in place of soap also gave inferior results.

Vermorel and Dantony (1912), continuing their investigations, concluded that the surface tension of a spray solution is not an index of its spreading power. Solutions with different surface tensions may have the same ability to spread, or the spreading power may vary according to the nature or physical state of the material to be treated. Two distinctions are made: (I) Where the liquid is able to touch the surface, when it may spread as water on a potato leaf or may collect in a drop as water on a vine (grape) leaf; (2) where the liquid rests on the surface without touching it, as in the case of a drop of water on a cabbage leaf, a film of air being interposed between the leaf and the water. A solution of sodium oleate giving a stalagmometer reading of I 42 drops may spread over a cabbage leaf and fail to spread on the leaf of a vine. They believed that the surface tension of the spray influenced its spreading less than did its surface viscosity. Whereas the sodium oleate solution giving 142 drops from the stalagmometer failed to spread over the leaves of the vine, a saponin solution giving only IOI drops, and therefore apparently possessing a higher surface tension, spread readily. This difference is thought to be explained by the higher surface viscosity of the saponin solution, so that when spread in a thin film over the leaf, surface concentration rapidly took place, thus increasing the surface viscosity to such an extent that the solution was unable to collect in a drop. A gelatin solution of I part in Io,ooo parts of water, possessing a surface tension nearly equal to water, caused spreading when applied to the leaves of a vine. Gelatin in solution was more effective than either saponin or soap and had the further advantage of being uninfluenced by either acid, neutral, or basic materials.

In this as in the preceding paper (Vermorel and Dantony, I9ro), no mention is made of the speed of formation or the rate of detachment of the drops from the tip of the stalagmometer. Concentration of the materials in the surface layer reduces the surface tension, and since different materials may vary as to the time required to concentrate in the surface layer, these measurements of surface tension are not comparable. Further, if surface concentration takes place so rapidly as to cause the 
film to become so viscous that it can no longer collect in a drop, a decided lowering of the surface tension should be apparent in the stalagmometer readings. No consideration is taken of the possibility of a concentration of the materials at the interface of leaf and spray which would result in a lowering of the surface tension at the interface and tend to produce spreading.

Chappaz, G., (I913) recommends the use of saponin in preparing sprays which will spread well and considers it superior to soap. Chapaz (I9I3) reviews the recent work with spreaders, discussing soap, gelatin, glue, and saponin. He recognizes a general but not a mathematical relationship between spreading and the drop number determined by means of a Duclaux pipette (stalagmometer). Vermorel and Dantony (I9I3) recorded several methods of preparing fungicides with casein. A solution of casein is prepared by dissolving it in a solution of 100 grams of sodium carbonate to a liter of water. Parker (I9I3) used from 4 to Io pounds flour paste with lime sulphur and nicotine sulphate to each roo gallons of liquid. The spray was used primarily for red spider and was tried on several different plants. Altho it was an effective spreader on many plants, it failed when used on carnations, sweet peas, and greenhouse roses. The possibility of its use as a "sticker" for lead arsenate suspensions was considered. Glue and miscible oil mixed with lime sulphur was used for the control of red spider by Jones (I9I3). Excellent spreading was reported on all parts of plum and peach trees and it is believed that similar results would be obtained on citrus trees. Neüls (1913) confirmed the results of Parker (1913) on the spreading properties of lime sulphur and flour paste and the value of this spray for the destruction of red spider.

Lafforgue (1913) points out that spreading and adherence are two entirely different phenomena. The addition of saponin to the spray mixture gives good spreading but not good adherence, while gelatine spreads well and also improves the adherence.

Lefroy (1913), working in India, had determinations made of the surface tension of the solutions used for controlling psylla attacking indigo. Soap solutions showed a very much lower surface tension than water, but soap emulsions of oil or creosote exhibited a higher surface tension than the soap solution alone. These results are opposed to the work of Gastine (1912), who found that a saponin emulsion of beechwood creosote or coal-tar creosote possessed a lower surface tension than the saponin solution. However, since no mention is made by Lefroy of the method employed in determining the surface tension, and in view of the fact that in one case soap and in the other saponin was used to emulsify the creosote, no conclusion can be reached as to the accuracy of the results. 
Astruc (I9I3) divides spreaders into four types: (I) Soaps; (2) saponins; (3) albuminous substances, such as albumin, gelatin, milk, dried blood, and casein; (4) organic salts of more or less limited production. No mention is made as to the nature of these organic salts. Issleib (I9I4) extracted 2 kilograms of "carrangeen," or pearl moss with Ioo kilograms of water. The extract, a thick slimy liquid, when sprayed over the leaves formed a thick continuous coating which on drying cracked and scaled off, carrying with it the larvae or eggs of insects infesting the plant. These results are comparable to those recorded by Parker (1913), using flour paste, and no doubt this preparation would give similar spreading.

Del Guercio (1914), in Italy, recommended the use of I to 2 per cent of flour-paste, fish glue, or other colloidal substance, with potassium or calcium polysulphide to give an even distribution of the spray over citrus trees to control Chrysomphalus dictyospermi var. pinnulifera. Rye flour is preferred, but spoiled wheat flour or the flour of other grains may be used. An even distribution was obtained regardless of the degree of maturity or the position of the treated portions. Arnal (I9I4) mentions that "soluble caseins," for use with bordeaux mixture, are being manufactured in France and put on the market. It may be that these preparations are similar to the casein glue being sold in the United States.

Vermorel and Dantony (I9I5) prepared rapidly a calcium caseinate by stirring a liter of milk of lime into a suspension of roo grams of casein powder in a liter of water. The milk of lime may contain from 50 to 200 grams of lime without influencing the results. One liter of this solution is added to a hectoliter of alkaline bordeaux mixture to give spreading and adherence.

The most important paper, following the papers of Vermorel and Dantony, dealing with the spreading of sprays, is that of Lefroy (I915). The fact that spreading depends not only upon the value of the surface tension of the spray, but also upon the surface tension of the leaf ${ }^{2}$ and the surface tension at the interface of the spray and the leaf, is presented by Lefroy for the first timè in entomological literature. Unfortunately Lefroy becomes confused in his terms, and draws the incorrect conclusion that if the surface tension at the interface between the spray and the leaf is greater than the sum of the surface tension of the spray and that of the leaf, spreading will occur. Realizing that the surface tension of the leaf and the surface tension at the interface of leaf and spray can not be readily determined, he recommends the determination of the surface tension of the spray, which should be as low as possible. Using the term "wetting" to denote the specific attraction

2 Solids are usually considered as possessing a surface tension altho it has not been demonstrated. 
or slight chemical affinity existing between the spray and the leaf, the statement is made that "spreading of a liquid over a surface it never wets" may occur. This conclusion does not appear to be justifiable, since if no wetting occurred the surface tension at the interface would be so high that spreading would be impossible. The theory of spreading of both sprays and dips is presented in a very interesting paper by Cooper and Nuttall (1915). First pointing out the value of having sprays and dips which will spread over the treated plant or animal, they give the principles of spreading established by Quincke (I877). Quincke studied the capillary rise of liquids in tubes of different materials, the spreading of one liquid over another liquid or a solid, and the angles formed by the liquid at its point of contact. From this study he formulated the conditions necessary for spreading to occur. These conditions in terms of sprays may be expressed by the statement that if the surface tension of the solid (leaf) is greater than the sum of the surface tension of the spray and the surface tension at the interface of spray and solid, spreading will occur. Cooper and Nuttall believe that in general this statement holds, but believe that there may be certain exceptions. Two factors are thought to be able to upset entirely this relationship. The first of these is the solvent action of the liquid on the solid, particularly in those cases where the solid is coated with wax or grease. This solvent action of the spray is believed to be independent of the surface tension at the interface of solid and liquid, but as will be shown later in this paper the solvent action of one liquid on another liquid or a solid, results in the lowering of the surface tension at the interface. Sprays, therefore, which spread because of their solvent action, are not exceptions but actually fulfil the surface tension conditions necessary for spreading to occur.

The second factor considered as vitiating the surface tension equation is the phenomenon of surface concentration. The experiments of Vermorel and Dantony are cited as showing that a spray with a high surface tension spreads well owing to its high surface viscosity resulting from a rapid surface concentration of the solute.

Since these experiments have already been discussed and will be taken up later they will not be considered further here, tho it may be said that in the opinion of the writer, they do not invalidate the surface tension relations already expressed.

Having presented the problem, Cooper and Nuttall take up the possibility of measuring the spreading power of dips and sprays. The work of Vermorel and Dantony is thought to show that the measurement of surface tension alone is insufficient to determine the spreading qualities of the liquid. The ability of the spray to produce a foam, since it depends upon surface tension and does not express the surface tension at the interface of the liquid and solid, can not be used as an index to 
spreading. The weight of the quantity of liquid adhering to a solid dipped into it is largely influenced by viscosity, and is therefore not considered an accurate method of determining spreading. Spreading may be conveniently expressed by the formula $\measuredangle s>\succ 1+\succ$ ls where " $\varnothing$ " represents surface tension; "s", solid; "l", liquid; and "1s", the liquidsolid interface. Then $\gamma s-(\gamma 1+\gamma 1 s)=$ the spreading power of the liquid expressed in dynes. Cooper and Nuttall, being chiefly interested in dips where the solid is represented by the skin of the animal, usually oily in character, adopted castor oil or liquid vaseline as a liquid substitute for the solid. This substitution simplified the problem, as the surface tension of the oil and of the liquid (dip) could easily be measured and expressed in dynes. Using a modification of the drop pipette method for determining the emulsifying action of soap solutions, they measured the surface tension at the interface of the oil and the dip. Substituting the values of the different surface tensions in the above formula, a definite value for spreading, expressed in dynes, was obtained. It is pointed out, however, that this method is applicable only to soap solutions and will not give results with gelatine, saponin, or similar solutions.

This method, based on the use of an oil as a substitute for the solid, may be used only when the solid is oily or greasy, and can not be used to determine the spreading power of sprays on leaves which possess an entirely different surface.

From the results of their experiments they conclude that for comparative values the interfacial tension alone may be considered. Since this is inversely proportional to the number of drops produced by a given volume of the oil, and since the spreading varies inversely as the interfacial tension, it is directly proportional to the drop number. This conclusion, however, is based on the assumption that the liquid has a low surface tension, which, altho correct in the case of soap solutions, is not always true of spray materials which will spread. Of the two surface tensions, they consider the surface tension of the solid-liquid interface more important.

A new material and one well adapted for use in certain countries was suggested by High (I9I5). Fifteen pounds of cactus leaves sliced and soaked in 50 gallons of water over night is recommended as a spreader. Cactus extract gave excellent results when used with zinc arsenite, and paris green and lime, but with lead arsenate the results were unfavorable, owing to the formation of a precipitate. Cactus grown near water contains a lower percentage of the desired material and hence larger quantities were required to give the desired results.

Smith, L. B. (1916), using the method of finding the surface tension at the liquid-solid interface suggested by Cooper and Nuttall, determined the spreading power of various combinations of fish oil soap 
and nicotine sulphate. No effort was made to determine the surface tension of either the oil or the spray. The sprays were tested with Acyrthosiphum pisi Kalt. on garden peas, Myzus persicae Sulz. on spinach, and Tetranychus sp. on strawberries. The maximum killing was reached with certain concentrations of soap or soap and nicotine sulphate. Further additions of soap failed to increase the efficacy of the spray. Using a fixed concentration of soap and increasing the concentration of nicotine sulphate reduced the spreading and also the killing power of the spray. This result was undoubtedly due to the reaction between nicotine sulphate and soap.

Lees (I9I7) tested the spreading of paraffin (kerosene) emulsion on cloth surfaces previously painted with boiled linseed oil and dried. A drop of the emulsion was rolled about on this surface and arbitrary values from one to three were used to express the degree of spreading of the kerosene and similar values for the aqueous phase. Based upon these preliminary tests, further experiments were made on the spreading of water solutions of gelatin, casein, soap, and paraffin emulsions on the leaves of gooseberry and sea kale and on goosebrry mildew. All the preparations gave complete spreading on gooseberry leaves but only certain of the emulsions gave complete spreading on kale leaves and gooseberry mildew. No attempt is made to explain the results.

Altho not directly bearing on the spreading of sprays on foliage, the experiments of Gray (I9I8) in preparing "wettable" sulphurs are of interest. An ounce and a half of powdered glue dissolved in 3 gallons of water thoroly wets, or spreads over, powdered sulphur, thus making possible the formation of a suspension.

Lovett (I9I8) studied spreaders for arsenate sprays. Spreading is thought to be caused largely by surface tension and specific gravity. It is stated that the ability of the liquid to hold the arsenate in suspension is a very fair indication of its ability to spread. This is not always true, for altho some spreaders which increase the viscosity of the medium also reduce the rate at which the suspended particles settle, this characteristic in itself can not be considered an index of spreading. Soap, glycerine, glue, casein, and an infusion of sage were tes.ed as to spreading ability and also as to the degree of injury they produced on bean foliage. An infusion of sage made by steeping Artemesia trildentata, Nutt, for twelve hours gave very encouraging results. The oils and other ingredients present in the infusion were not determined but were considered as probably similar to those found in Artemesia frigida, Willd. by Robak (1906). This species was shown to contain an essential oil composed primarily of borneol camphor and cineol. From 4 to 8 ounces of casein converted into calcium caseinate and added to each Ioo gallons of spray gave good spreading. 
Stearns (I920) experimented with the "Irish" moss which is similar to that used by Issleib (I9I4), as a spreader of arsenical substances over peach foliage. Issleib's proportion of 4 pounds to 20 gallons was found to be too thick for spraying purposes, but when used at the rate of 4 pounds to 50 gallons gave good results. Calcium caseinate at the rate of I pound to 50 gallons also gave good results on peach foliage.

The most recent paper dealing with spreaders is that of Lovett (1920). In discussing the suspension test as an index of spreading, he says that altho not a definite criterion of spreading it "does indicate a " physical quality in the solution much to be desired in a spreader." His belief that increased viscosity is accompanied by increased spreading is shown in the experiments where phosphates and sulphates are added to aqueous solutions of glue and of calcium caseinate to increase the viscosity and therefore the spreading. Increased spreading was not obtained.

A number of different materials were tested, not only colloids such as saponin, sage tea, gelatin, glue, calcium caseinate, corn, potato, wheat, arrowroot, and starch, but also inorganic substances such as aluminum sulphate with lime, kaolin, barium sulphate with lime, chromium fluoride with lime, calcium chromate with lime, and lead chromate with lime. None of the inorganic materials gave the desired results. On the basis of compatability, efficacy, availability, cost, and ease of preparation, he arranges the colloids in the following order of merit: Calcium caseinate, glue, gelatin, soap bark (saponin), and oil emulsion.

A new method for testing spreading in the laboratory is presented. Tubes lined with a coating of wax obtained from the surface of Ben Davis apples were used to determine the capillary rise of the different solutions. The numerical value of 3.5 (probably millimeters) is given for water, while 2 per cent gelatin had a value of II.8, 2 per cent soap bark 28,2 per cent caseinate Io.I I, and 2 per cent glue 7.8. Lovett believes that the height to which the liquid rises in the capillary tube is a measure of spreading power. This is not strictly true, as only those liquids which will spread over or "wet" the surface of the tube (in this case the wax of the apple) will rise in it, and the height to which they rise is determined by the surface tension of the liquid and the angle of contact of the liquid to the wall of the tube. The use of a capillary tube will merely show whether the liquid will or will not spread. If it rises at all, spreading will occur; and if no spreading will occur there will be no rise.

Summarizing briefly the work of the various investigators, it is apparent that various colloidal substances, such as casein, gelatin, flour, glue, and soaps modify the spray mixture to such an extent that it will remain spread out over the leaf surface in the form of a film. The surface tension relationships of the leaf and spray offer the best explanation, but in certain cases other factors are thought to influence the 
results. These various colloidal substances have given good spreading on leaves with a thin cellulose epidermis, and even on leaves more or less strongly cutinized, such as those of apple, peach, grape, pear, and the citrus fruits. Results on waxy surfaces, such as the waxy bloom on the fruit of apple or plum and the leaves of cabbage, have not been attained except by the use of soap or soap emulsions. Soap will produce spreading on such surfaces, but owing to the reaction between the soap and the arsenical materials, its use may result in injury to the foliage. Other disadvantages of the use of soap are its varying composition, its reaction with hard water, and the difficulty of dissolving it without the use of heat. The following experiments were therefore undertaken to find a new material for use on waxy surfaces, and to obtain a better understanding of the causes governing spreading.

\section{THE THEORY OF SPREADING}

The manner in which surface tension is related to spreading is shown by the following illustration. Upon a liquid, B, with a surface exactly two square centimeters in area, place a drop of an immiscible liquid, $\mathrm{A}$, so that its area is exactly one square centimeter. The area of the surfaces of $A, B$, and the surface at the interface $A B$ is then exactly one square centimeter in each case, and the surface tension of the entire system is expressed by the equation $\gamma A+\succ B+\gamma A B$, in which $\succ$ represents the surface tension. Now assume that $A$ is spread out until it completely covers $B$, then the area of the surface of $A$ and the surface at the interface $A B$ is in each case two square centimeters, while $B$ no longer has an exposed surface. The surface tension of the system then becomes $2 \succ \mathrm{A}+2 \succ \mathrm{AB}$. Subtracting the second equation from the first gives the equation $\succ \mathrm{B}-\succ \mathrm{A}-\gamma \mathrm{AB}$ as the difference between the surface tensions of the system under the two conditions. Since a system will always arrange itself so as to reduce its surface tension, if the surface tension of the system in the second state is less than in the first case, spreading will occur and the equation will be positive. If the surface tension under the original arrangement is the lowest, then the equation is negative and spreading will not occur. The surface tension conditions favorable to spreading may then be represented by the equation $\succ \mathrm{B}>\succ \mathrm{A}+\succ \mathrm{AB}$, while conditions unfavorable to spreading may be expressed by the equation $\gamma \mathrm{B}<\gamma \mathrm{A}+\gamma \mathrm{AB}$. An excellent example of these conditions is the system benzene and water. A drop of pure benzene placed on the surface of pure water immediately spreads out, forming a thin film ${ }^{3}$.

$$
\begin{gathered}
\succ \mathrm{H}_{2} \mathrm{O}>\gamma \mathrm{C}_{6} \mathrm{H}_{6}+\gamma\left(\mathrm{H}_{2} \mathrm{O}-\mathrm{C}_{6} \mathrm{H}_{6}\right) . \\
\gamma=72.05>\gamma=28.17+\gamma=34.68 .
\end{gathered}
$$

${ }_{1}^{3}$ The surface tension values given are those of Harkins, Brown, and Davies (1917). 
In a few minutes the water becomes saturated with benzene and the benzene becomes saturated with water. The surface tension of each is lowered, while the surface tension at the interface is increased. The value for the equation becoming :

$$
\begin{gathered}
\gamma \text { Sat. } \mathrm{H}_{2} \mathrm{O}<\gamma \text { sat. } \mathrm{C}_{6} \mathrm{H}_{6}+\gamma\left(\mathrm{H}_{2} \mathrm{O}-\mathrm{C}_{6} \mathrm{H}_{6}\right) . \\
\gamma=6 \text { o.I9 }<\gamma=27.90+\gamma=44.68 \text {. }
\end{gathered}
$$

The benzene which had previously been spread out in a thin film now collects in the form of a drop. In this case, at least, there is no doubt that spreading or lack of spreading may be explained on the basis of surface tension.

Unfortunately it is at present impossible to measure the surface tension of a solid, or even to prove conclusively that a solid possesses surface tension. Since the surface tension of a liquid increases as the temperature is lowered, even to the freezing point, it does not appear reasonable that surface tension completely disappears in the solid. It seems more reasonable to believe that a solid has a high surface tension which can not be demonstrated because of the immobility of the molecules. The surface tension at the interface of the solid and liquid is also impossible of measurement. With two of the surface tensions unknown, it is useless to measure the surface tension of the spray liquid, and it becomes necessary to find some other method of solving the problem.

From a consideration of the above formula, it appears that spreading can be obtained only by lowering the surface tension of the liquid or the surface tension at the liquid-solid interface, since the surface tension of the solid (leaf) can not be increased. The problem, therefore, resolves itself into this: How may the surface tension of the spray and the surface tension at the spray-leaf interface be lowered? It is well known (Willows and Hatschek, I9I5) that the adsorption of a solute in the surface layer will result in the lowering of the surface tension, while if it is negatively adsorbed, the surface tension will be increased. Thus soap or saponin dissolved in water is adsorbed or collects at the surface and the surface tension lowered. Sodium chloride dissolved in water concentrates in the interior of the liquid and is therefore negatively adsorbed and the surface tension is increased. In a similar manner a dissolved substance adsorbed in the surface at the interface of the liquid and solid will lower the surface tension at this interface. The next question then is to determine what substances will be positively adsorbed in the liquid-air surface and the liquid-solid surface.

Data on this problem have been given in three different papers which are too long to be completely reviewed here. Altho the papers deal with a different problem, certain facts given in them may be directly applied to the present problem. Harkins, Brown, and Davies (I9I7), considering the work done when water and some other liquid come 
together to form an interface, have shown that at the interface of the two liquids the molecules in the surface of the liquid orient themselves so that the active group is in contact with the water. The decrease in the free energy, i.e., the surface tension at the interface, when the surface of a second liquid approaches that of water, depends primarily on the most active group present in the molecules and secondarily on the shape and size of the molecules. The solubility in water is related to this decrease in free energy which more or less perfectly measures the attraction of the active group for the water molecule. The presence of such active groups as $\mathrm{COOH}, \mathrm{CO}, \mathrm{CN}, \mathrm{OH}$, or $\mathrm{CONH}_{2}$ is sufficient to make the molecule of an organic substance soluble in water, providing the active group does not have to pull into the solution a slightly less active group, which is too long or too large.

In a second paper Harkins, Davies, and Clark (19I7) show that in the surface of a liquid the molecules are so oriented that the least active group is toward the vapor phase, that is, the vapor above the liquid. At any surface or interface, the orientation of the molecules is such as to make the transition to the adjacent phase-that is, the vapor, liquid, or solid in contact with it-least abrupt. At the interface of two liquids their like parts come together in conformity with the above law. In two liquids, $\mathrm{A}$ and $\mathrm{B}$, the portion of the molecules of $\mathrm{A}$ like $\mathrm{B}$ turn toward $\mathrm{B}$ and those of $\mathrm{B}$ like $\mathrm{A}$ turn toward $\mathrm{A}$. If a solute is present in either of the liquids, A or B, which collects at the interface, the molecules of the solute will so arrange themselves that the parts of the molecules which are like $A$ will turn toward $A$, while those like $B$ will be attracted to B. In such a case the free surface energy, that is, the surface tension at the interface, will be reduced. An aqueous solution of a solute which is active like water but to a lesser degree, will be positively adsorbed in the surface and the least active portion will be turned toward the outside.

The third paper by Langmuir (19I7) approaches the problem from a slightly different angle. Studying the spreading of oleic acid on water, the conclusion is reached that the active carboxyl groups are actually dissolved in the water but the long hydrocarbon chains have too much attraction for each other to be dissolved, hence the acid spreads out into a thin film. Oils without this carboxyl group should not spread, and in fact pure paraffin oil, which lacks an active group, fails to spread at all. Results show that the spreading of films on surfaces is determined by the shape of the molecules and by the relative activities of the different portions of the molecule. In a similar manner a substance, such as a soluble fatty.acid, dissolved in water, is adsorbed in the surface layer and lowers the surface tension. Adsorption of a liquid on a solid is considered as similar to the spreading of oil on water, i.e., the portion 
of the liquid similar to the solid is attracted by the molecules of the solid forming a molecular layer upon it.

Considering the data presented in these papers, the investigation became a search for those substances which possess an active group to render them soluble in water and an inactive group which will cause their adsorption in the surface layer. If the inactive group should be similar to the surface of the leaf or soluble in it, then adsorption at the spray-leaf interface would occur and would result in a lowering of the interfacial tension. A substance fulfilling one or the other of these conditions, preferably the latter, should cause spreading.

\section{SPRAYS THAT WILL SPREAD ON CABBAGE LEAVES}

An effort was made by the author in the earlier experiments to determine whether a given solution would spread or not, by means of capillarity. Altho this method might be used in considering waxy surfaces, it could not be adapted to the study of leaves with a thick cuticle. To obtain comparable results, nothing but a capillary tube possessing walls exactly similar to the leaf surface would suffice. Tests in all the experiments were therefore made by spraying the solution on the surface of the leaf by means of an atomizer.

The first efforts were directed toward producing spreading of the spray on cabbage leaves. A saturated solution in water of several organic compounds was tested. Solutions of kerosene, methyl salicylate, benzaldehyde, chloroform, camphor, and salicylic acid failed to give the desired results. - Amyl alcohol and benzyl alcohol gave good results but were too expensive for actual use. Crude phenol produced spreading but since a I per cent solution of pure phenol failed, the results with crude phenol must have been due to impurities. Phenol possesses an active $\mathrm{OH}$ group, while resorcinol possesses two such $\mathrm{OH}$ groups. A I per cent solution of resorcinol failed to give spreading. It appeared therefore necessary to introduce such groups in the phenol as would decrease its solubility in water and increase its solubility in the wax of the cabbage leaf, thereby increasing its adsorption at the leaf-spray interface and lowering the interfacial surface tension. A saturated solution of beechwood creosote consisting of a mixture of cresols, $\mathrm{C}_{6} \mathrm{H}_{4}(\mathrm{OH}) \mathrm{CH}_{3}$; and guaiacol, $\mathrm{C}_{6} \mathrm{H}_{4}(\mathrm{OH}) \mathrm{OCH}_{3}$, gave excellent results. So concentrated a solution of beechwood creosote is not necessary, since a good spreading accompanied the use of a one-third and even a one-fourth per cent solution. One-fourth per cent is about the lower limit and onethird is a safer proportion. A saturated solution of carvacrol, $\mathrm{C}_{6} \mathrm{H}_{3}\left(\mathrm{OH}\left(\mathrm{CH}_{3}\right) \mathrm{C}_{3} \mathrm{H}_{i}\right.$, containing about one-twelfth of I per cent, and a saturated solution of eugenol, $\mathrm{C}_{6} \mathrm{H}_{3}(\mathrm{OH})\left(\mathrm{OCH}_{3}\right) \mathrm{CH}_{2} \cdot \mathrm{CH}$; $\mathrm{CH}_{2}$, containing only about one-fifteenth to one-twentieth of I per 
cent, gave good spreading, each being less soluble in the water and more soluble in the wax of the leaf. ${ }^{4}$

Most of these substances are adsorbed in the surface layer and reduce the surface tension of the solution. The question naturally arises whether the spreading is not caused by the lowering of the surface tension of the liquid itself rather than the lowering of the surface tension at the interface of the leaf and the solution. Surface tension determinations were therefore made by means of a stalagmometer. Harkins and Brown (I918), in studying this method of determining surface tension, pointed out that if the formation of the drop is too rapid, some of the liquid streaming from the tube seems to force its way into the falling drop during the time of detachment, hence increasing its weight. From the figures given, this error is not very large and can be ignored in these relative determinations. It is also stated that when dilute aqueous solutions of long chain organic molecules are used, it is often necessary for the drop to hang for half an hour to obtain the value of the static surface tension. In spraying it is really the surface terision of the solution at the moment it is sprayed over the leaf that is desired, hence a determinatin of dynamic surface tension is more important than static surface tension.

A one-third per cent solution of creosote allowed to drop at the rate of one drop per minute showed a surface tension of 49.27 dynes. One-fourth of a pound of sodium oleate to Ioo gallons of water possessed a surface tension of 42.42 dynes. The soap solution, altho it possessed a lower surface tension than the creosote solution, failed to spread over cabbage leaves. A soap solution with a surface tension of 24.28 dynes gave spreading. It is therefore apparent that the spreading of the creosote solution is not owing to its low surface tension but to the lowering of the surface tension at the leaf-solution interface. Further confirmation of this statement is found in the fact that none of these solutions would spread over the leaves of citrus, guava, or other plants possessing strongly cutinized leaves but lacking the waxy surfaces.

The possibility that the results of Lovett (I918) with sage infusions may have been due to some organic principle in the essential. oil of the sage, at once suggested itself. Robak (I9I2) has shown that another species of sage possessed an oil rich in cineol, hence a saturated solution of cineol was tried and gave good results. Since this experiment was conducted, Lovett (1920) has stated that sage infusions did not spread well over the waxy surface of apples, hence his results may have been due to some other ingredient of the infusion.

${ }^{4}$ A saturated solution of a mixture of xylenols sold under the name of cresylic acid (straw-colored) by the Barrett Co. will cause spreading on cabbage leaves. 
No doubt a very large number of organic compounds will give similar results. Apparently all that is needed is a chemical containing an active group to make it slightly soluble in the water, and an inacive portion soluble in wax. With this principle as a base, it should be a simple matter to select the compound best suited for each particular set of conditions. The practical application of these results has been left for future investigation.

\section{SPRAYS THAT WILL SPREAD ON OTHER LEAVES}

It has been stated that these organic solutions failed to spread on leaves which did not possess a waxy coating. Other investigators have obtained good spreading on such leaves by means of various colloids, such as soap, casein, glue, and gelatin. Sodium oleate, 2 pounds to IOO gallons, gave spreading on citrus leaves, while a smaller quantity failed. Commercial casein was dissolved in water containing a very small quantity of sodium hydroxide ( 2 ounces to 5 pounds of casein). Such a solution containing only one-fourth pound of casein to IOO gallons of water gave very good spreading on citrus leaves, but failed on cabbage unless applied with such force that the liquid penetrated between the wax particles, reaching the epidermis below. Gelatin used at the same rate also gave favorable results on citrus leaves. Acidifying the solution did not destroy its spreading properties.

Flour paste has often been used as a spreader, but much of the protein in the flour is insoluble in water and is therefore not utilized. If about one ounce of sodium hydroxide is added to 5 pounds of flour when the paste is being prepared, all of it goes into solution. Prepared in this way, one-fourth pound of flour to each 100 gallons of the spray produces a film when sprayed over citrus leaves.

Saponin gives good results but is too expensive for general use. Jacobson (1919) has shown that alfalfa hay contains a saponin quite soluble in water. About one per cent of pure saponin was recovered from air-dried alfalfa. Alfalfa hay should therefore serve as a spreader. One hundred grams of hay was heated in 3 liters of water and allowed to stand twenty-four hours. Two and a half liters were recovered on straining. This solution was diluted until it represented only sixtenths of I per cent of alfalfa hay, and at this dilution gave good spreading. Five pounds of dry alfalfa would be sufficient for 100 gallons of the spray.

The question arose as to whether these results were due to the lowering of the surface tension of the liquid, to the increased surface viscosity suggested by the work of Vermorel and Dantony, or to a concentration of the materials at the leaf-spray interface, resulting in a lowering of the interfacial tension as suggested by the experiments with waxy leaves. A creosote solution with a surface tension of 49.27 dynes 
failed to spread, as did also a soap solution of 38.36 dynes, while one with a surface tension of 24.28 dynes gave good spreading. A solution of gelatin of I part in 10,000 which will produce spreading had a surface tension of 72 dynes. Casein in solution, alkaline to litmus, had a surface tension of 64.4 dynes, while when acid to litmus the surface tension was lowered to 57.74 dynes. These values were obtained by allowing one minute for the drop to fall from the tip of the stalagmometer, and therefore represent the dynamic rather than the static surface tension. Since the spreading occurs on the leaf at once,.it is apparent that the results are not due to a low surface tension.

Vermorel and Dantony (I912) explained similar results on the basis of a very rapid surface concentration of the colloid resulting in an increase in the surface viscosity so great that the film was prevented from collecting in a drop. If such a rapid concentration occurred, it should make itself manifest by its influence on the surface tension. The number of drops produced from a given volume of liquid when measured by allowing one second for each drop, compared with the number obtained when one minute was allowed, should be a fair test of the rapidity of the surface concentration which might occur on the - leaf surface quickly enough to make the surface so viscous that the film could not collect in drops. Water measured at the rate of one drop per second gave 45.5 drops while at the rate of one drop per minute 46 drops were produced. Gelatin, I part in ro,ooo, gave 46 and 46.5 drops; while casein, 3 parts to Io,ooo, gave 46 and $5^{2}$ drops when alkaline to litmus and 50 and 58 drops when acid to litmus. This increase does not appear sufficient to produce as high a surface viscosity as Vermorel and Dantony considered possible. Harkins and Brown (I9I8) found that the surface concentration is so slow in such solutions that a half hour must be allowed each drop to insure the maximum surface concentration and a true measurement of the static surface tension. Further, if the spreading is due to surface viscosity it should be possible to produce the film on any surface, but this can not be accomplished.

Like material has been shown to attract like, and there is a strong similarity between the colloids used and the cellulose and cutin of the leaf surface. This similarity should cause a concentration in the surface at the interface of the leaf and spray, thus reducing the interfacial tension. On the cabbage leaf the contact is with the wax, different in character from the proteins, and spreading is not obtained. Only when the spray is delivered with sufficient force to drive the liquid between the wax particles and bring it into contact with the epidermis will results be obtained. 


\section{CONCLUSION REGARDING THE PHENOMENON OF SPREADING}

On the basis that substances of like nature attract each o:her, materials were selected which, while soluble in water, would be attracted to the leaf surface and concentrate in the leaf-spray interface. Using materials similar in character to the wax of the cabbage leaf produced spreading but failed with leaves which did not possess the waxy coating. Protein and similar materials produced spreading on leaves with a surface of cellulose or cutin but failed to give good spreading on waxy leaves. It appears possible that an infusion of nearly any plant would serve to give spreading to a spray for use on wax-free leaves, but this statement requires confirmation.

The viscosity of some of the sprays was increased, but in the case of carvacrol, beechwood creosote, and eugenol it was not materially altered. Viscosity, therefore, is not related to spreading. Surface concentration appears not to take place rapidly enough to increase the surface viscosity to such an extent as to prevent the film from collecting into drops. The surface tension of the leaf was not altered and the values for the surface tension of the liquids did not agree with the results obtained in spreading. The reduction of the interfacial tension appears to be the most reeasonable explanation of the facts. Unfortunately this surface tension has not yet been measured, nor has the concentration of the material at the leaf-spray interface been demonstrated. However, with this theory as a basis, sprays that will spread on the different types of leaves may be produced.

\section{HISTORICAL CONSIDERATION OF ADHERENCE}

THE USE OF- ORGANIC MATERIALS WITH FUNGICIDES

The adherence of spray materials was studied very early in the history of spraying. In one of the earliest papers, Millardet and Davis (I886) drew attention to the fact that cupric steatite powder possesses remarkable adhierence, owing to its extreme fineness. When it was demonstrated that plant diseases might be controlled by means of copper compounds, an effort was made to form on the leaf a coating of copper which would adhere well and serve as a barrier to the fungus. Crouzet (1899) recommended copper caseinate, prepared by adding raw milk to a solution of copper sulphate, as a yery adherent spray. Galloway (I89I) used molasses and also glue to give adherence to a mixture of copper sulphate and sodium carbonate. In the experiments of Girard (1892), molasses actually diminished the adherence of bordeaux mixture. Lavergne (I896) tested a "tannocuprique" spray, possibly copper tannate, bordeaux and sugar, and bordeaux mixture 
alone, for the control of black rot. Bordeaux mixture applied six days earlier than the other sprays gave the most satisfactory results. Cazeneuve (1898) published a paper on albuminous bordeaux mixtures, the original of which is not available. Bourcart (I9I3) mentioned the use by Cazeneuve of three types of albuminous bordeaux, one containing milk, one made with dried egg white, and one with dried blood. The bordeaux casein did not adhere better than bordeaux and sugar, but the other two types persisted on the foliage throughout the season. Bourcart cited only the name, hence it is not certain that he is referring to Cazeneuve (1898). Guillon and Guirand (I898) tested the adherence of different preparations to glass slides. They showed that the adherence of bordeaux mixture decreased with its age. The addition of I per cent molasses or three-tenths per cent gelatin increased adherence, while larger quantities decreased it. 'They also used 3 per cent soap with 2 per cent copper sulphate, a combination which must have resulted in the formation of a colloidal copper soap. In a second paper published the same year they give results of studies on the adherence of these materials to grape leaves. Bordeaux mixture with 2 per cent soap showed the greatest adherence, while gelatin or molasses gave poor resilts. Perraud (1898) studied the adherence to the fruit rather than to the leaves of the vine. Starch, dextrine, egg powder, and dried blood failed to increase the adherence of bordeaux mixtures. Resin, soap, potassium silicate, molasses, gum tragacanth, and glue increased the adherence in the order named. In a second paper Perraud ( 1898 ) recommends the use of resin dissolved in boiling sodium carbonate. This material was added when cool to copper sulphate to increase its adherence. Similar results were claimed for a mixture of 2 per cent of copper sulphate and 3 per cent of soap. An actual decrease in the adherence of bordeaux mixture due to the addition of turpentine was noted by Ravaz and Bonnet (1903). Resin slightly increased the adherence, but the difference in both cases was considered unimportant. In many of these investigations, the organic material was added to give both adherence and spreading and many workers believed that a spray which would spread would also adhere better. Vermorel and Dantony (1913) clearly distinguished between these two properties, pointing out that a spray may spread without showing any remarkable adherence, while excellent adherence may occur even if the spray does not spread well. Lafforgue (I9I3) also distinguishes between spreading and adherence.

These papers represent the development of one method of making fungicides adhere. In many cases the added material reacted with the copper, forming such compounds as copper saccharate, copper stearate, copper resinate, copper caseinate, and copper albuminate. Some of these compounds, colloidal when freshly prepared, gave an increased 
adherence as a result of the fineness and insolubility of their particles. The copper, being formed into a stable and insoluble compound, lost much if not all of its fungicidal value. This fact coupled with the physiological effects produced by coating the leaves with an insoluble preparation similar to varnish, resulted in the discontinuance to a very large extent of the use of such materials.

\section{THE USE OF ORGANIC MATERIALS. WITH INSECTICIDES}

In early experiments with arsenic preparations for the control of insect pests, investigators feared that the material might adhere too long. Spraying for the gypsy moth developed the use of lead arsenate, a slow-acting poison which could be applied in large quantities without injury to the foliage. Because of its low toxicity, it was necessary that it should adhere for a longer period. Fernald (1894) stated that it is highly desirable to add 2 quarts of glucose or molasses to each I 50 gallons of water to increase the adherence. The idea of using glucose to cause adherence was possibly the result of the use of sugar with fungicides, but lead arsenate gave no reaction with glucose. Lowe (I896) pointed out that the use of glucose did not increase the adherence of lead arsenate but that glue at the rate of 2 quarts to 45 gallons gave satisfactory results. Kirkland (1898) showed clearly by means of general observation, chemical analysis, and physiological tests on caterpillars, that the addition of glucose did not increase the adherence of lead arsenate. The glucose was washed off the leaves by the first shower.

Washburn (189I) found that the addition of whale oil or soft soap to the spray increased the adherence of paris green, probably because of its more even distribution. A finely divided solid is more adherent, but Marlatt ( 1897 ) showed that paris green when very finely pulverized was more injurious to the foliage. Sirrine (1898) recommended the use of a resin-lime mixture to cause paris green and bordeaux mixture to adhere to the leaves of cabbage and cauliflower. This mixture is really a resinate of lime prepared by making a stock solution of resin, fish oil, and lye, to which, after proper dilution, the lime and paris green are added. The paris green adheres to the particles of the calcium resinate and these in turn adhere to the leaves. Volck (19I3) used flour paste made of 4 pounds of wheat flour to Ioo gallons of water to increase the adherence of sulphur. Larger quantities of flour caused the dry film to scale off, while smaller quantities were insufficient to "stick" the sulphur.

Surface (1905) lists the materials used to increase adherence. These are resin-lime mixture, soap, resin added to kerosene and used in kerosene emulsion, molasses, glue, flour, and salt when used with 
lime sulphur. The use of salt is now generally recognized as having no influence on the adherence of lime-sulphur sprays.

Paste lead arsenate was shown by Astruc, Couvergue, and Mahoux (I9II) to be more adherent than a freshly prepared suspension of dry lead arsenate. The age of the diluted spray did not appear greatly to influence its adherence.

Parker (I9I3) pointed out the possibility of using flour paste with lead arsenate to increase the adherence as well as to produce spreading.

A new method of rendering arsenical materials rainproof or more adherent is given in U. S. Patent No. I I66387. The arsenical substance is coated with an insoluble metallic soap, copper stearate in the case of paris green and lead stearate in the case of lead arsenate. These products were marketed for a few years by the International Color Company, generally as a dry powder for dusting purposes, altho they also manufactured a paste form for general spraying.

Lees (I9I5), interested in lime preparations as cover washes for trees in late winter and early spring, tried to increase the adherence by the addition of various substances. Glue, flour, and farina (potato flour) gave good results. The best results were obtained with a mixture of whiting, starch, glue, and potassium bichromate. In a second paper (I916) he modified the formula, leaving out the starch. The potassium bichromate was added to the mixture because on exposure to light it reacts with glue, rendering it insoluble.

O'Kane, Hadley, and Osgood (1917), in a study of the arsenic retained by fruit after spraying with lead arsenate, give some data as to the actual adherence of lead arsenate. Altho not directly concerned with adherence, the percentage of arsenious oxide was determined on fruit picked from three to five days after spraying and before a rain had occurred. The fruit on other trees was not picked until much later, thus giving data for a comparison of adherence. Fruit picked so carefully that none of the lead arsenate was rubbed off, showerl an average of 0.37 milligram of arsenious oxide per apple, from three to five days after spraying and before rain occurred. An average for twenty-five apples, selected as showing the maximum amount of lead arsenate, was 0.77 milligram per apple. Fruit from other trees sprayed at the same time but picked seventy-five days later had 0.08 milligram and those picked after seventy-six days later had o.I I milligram per apple. "These trees were subjected to a total rainfall of 5 .0 I inches The average amount of arsenious oxide present on the fruit was 25.6 per cent. Fruit sheltered by the leaves would no doubt show a much higher percentage of arsenic than would normally be the case.

Gray (I9I8) found that the addition of glue to sulphur increased its adherence. The fact that dry lead arsenate was not so adherent as lead arsenate paste and also that the addition of molasses or sugar 
reduced the adherence, was confirmed by the experiments of Hartzell (I9I8). Stearns (1920) showed that the addition of Irish rock moss or calcium caseinate to the spray increased its adherence. Lovett (I920) considers that in general those substances which increase the spreading of a spray will also increase the adherence of the spray material.

\section{THE USE OF INORGANIC SUBSTANCES}

- The fact that certain inorganic substances adhere to the leaves better than do others was early noted. This fact led to the use of certain inorganic materials to increase the adherence of the spray materials. Compounds of chromium, aluminum, and more particularly iron, have been tried. Kilgore (I9II) combined london purple and paris green with ferrous sulphate and ferric chloride, but the mixture was not a success. Arsenious oxide combined with ferrous sulphate or ferric chloride gave a rather soluble mixture which proved injurious to the foliage. In these experiments adherence was not sought but rather a combined insecticide and fungicide. Girard ( 1892 ) added aluminum sulphate to bordeaux mixture to produce a greater adherence. The use of aluminum sulphate suggested itself to Girard because of its mordant character, but the results were not satisfactory. Fairchild (1894) noted-the remarkable adherence of ferrous ferrocyanide. This led to experiments with iron borate, ferric hydrate, and iron sulphide but no such remarkable adherence was noted. Smith (1907) tested an iron arsenate said to be a by-product in the preparation of ore: It contained 45 per cent of arsenious oxide. Used at the rate of r.2.5 pounds to Ioo gallons it killed the larvae of the elm leaf beetle without injury to the foliage. The plants were sprayed July $I 7$ and on the I8th a heavy rain occurred and another lighter rain on the 2oth. Little trace of the material was found on the $22 \mathrm{~d}$. Selby (1908) proposed a modified formula for bordeaux mixture in which the amount of copper sulphate was reduced and a large quantity of iron sulphate was added to serve the purposes of a "sticker." The formula was

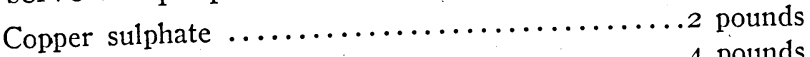

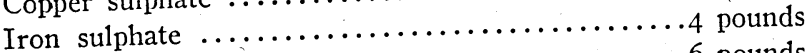

Quicklime

Water to make 50 gallons.

The spray was rust colored and showed great adherence. $\mathrm{He}$ considered that the iron sulphate (probably ferrous) was precipitated by the lime in the form of iron hydroxide. Pickering (I907), however, has shown that the reaction of ferrous sulphate and lime forms a precipitate of a basic iron sulphate, evidently of the formula io $\mathrm{FeO} \mathrm{SO}_{3}$. Volck (1909) prepared an iron sulphide spray by adding ferrous sulphate to lime-sulphur solution. The addition of 20 pounds of iron sulphate to 200 gallons of lime-sulphur spray mixture gave a 
black muddy precipitate of sulphur, iron sulphide, and calcium sulphate. This spray proved very effective for powdery mildew of apple.

A definite ferrous arsenate was prepared by Vermorel and Dantony (1909). A solution of 400 grams of ferrous sulphate in Io liters of water was added and stirred into a solution of 400 grams of sodium arsenate in Io liters of water, until a test paper impregnated with potassium ferro- and ferricyanide became a clear blue color. Diluting this mixture to Ioo liters, it contained 200 grams of ferrous arsenate to the hectoliter. On exposure to the air, as in spraying, the ferrous arsenate forms ferroso ferric arsenate and the ferrous hydrate becomes ferric hydroxide. It is pointed out that ferric hydroxide is an antidote for arsenic poisoning, which fact may explain why very large amounts of this preparation were not injurious to the foliage of plants. Vines were not injured by a proportion of 500 grams to a hectoliter; while pears, apples, and prunes were not injured by a spray containing 2 parts in I0O. Used at the rate of IOO to 200 grams to I hectoliter, ferrous arsenate successfully controlled the codling moth, Carpocapsa pomonella, in experiments extending over three years. Vermorel and Dantony (1909), in another paper, point out that ferrous arsenate can not be successfully combined with bordeaux mixture because of the formation of cupric arsenate, which is injurious to the foliage. They also say that ferrous arsenate alone shows great adherence, but that this adherence is reduced if glucose or molasses is added to the spray. Dalmasso (I9I0) used ferrous arsenate prepared according to the formula of Vermorel and Dantony for grape spraying in Italy, finding it not quite so effective as lead arsenate. No particular adherent properties are recorded. In America, Smith (I9IO) used a similar ferrous arsenate, successfully controlling the potato beetle and the elm leaf beetle. No special mention is made of the adherence. About this time several insecticide manufacturers put ferrous arsenate on the market in the United States. One of these, analyzed by' Bradiley (I9IO), showed 84.25 per cent of water, only 7.37 per cent of arsenic oxide, and $5.5 \mathrm{I}$ per cent of ferrous oxide. The dry ferrous arsenate contains from 50 to 55 per cent of arsenic oxide and from 40 to 45 per cent of ferrous oxide. Melander (I9II) tested both home-made and commercial ferrous arsenate for the control of the codling moth. One pound to 125 gallons of water was used, the trees having 0.37 per cent of wormy apples compared with o.I6 per cent for those sprayed with lead arsenate, and $2 \mathrm{I}$ per cent for unsprayed trees. Melander said that ferrous arsenate may be successfully combined with linie sulphur. Scott and Siegler (I9I5) tested ferrous arsenate in both laboratory and field experiments. It was found to be a slow-acting poison requiring fairly large doses to insure success. On the other hand, it was considered a safe arsenical substance for use on sensitive 
plants, even 2 pounds of chemically pure ferrous arsenate to 50 gallons of water being used on beans and peach without injury. High (I9I5) considered ferrous arsenate a very desirable spray, since it remains in suspension for long periods and shows no injury on delicate foliage. Ferrous arsenite did not show these desirable qualities. Ferrous arsenate was successfully combined with the cactus extract used for spreading.

Howe (I9I0) tested the iron sulphate-bordeaux mixture recommended by Selby (1908), finding it a less effective fungicide than standard bordeaux mixture, but more adherent and less injurious to the foliage. Waite (I9IO) used two fungicides containing iron sulphate; One a 3-3-50 bordeaux with 2 pounds of iron sulphate, and the other self-boiled lime sulphur plus 3 pounds of iron sulphate. It was observed that iron sulphide spray adhered so strongly as to give the plants a brownish appearance which did not wear off until picking time. It increased the greenness of the foliage and fruit to such an extent that the fruit was late in ripening. Ballard and Volck (I9I4) pointed out that the chief value of iron sulphide spray as a fungicide is due to the presence of precipitated sulphur, no claim being made of superior adherence. Stewart (I9I5) mentions the addition of iron sulphate to lime sulphur to reduce the injury to the plants and to increase the "sticking" quality of the spray. Lees (I9I5) used aluminum sulphate, iron sulphate, and potassium bichromate with lime to increase its resistance to rain. Aluminum sulphate was introduced because of the gelatinous character of precipitated aluminum hydroxide. In some cases fair results were obtained but they were not equal to those obtained by the use of organic materials such as glue and flour, and hence are not recommended.

In recent years in a few places in the United States a rain-proof arsenical material has been placed on the market.' This preparation contains chromium and arsenic, possibly a chromium arsenate, and when mixed with water forms a bluish-green suspensoid. Great adherence is claimed for this product by the manufacturers.

Summarizing the review of the literature it is found that in general a finely divided material will adhere better than a coarse material. The use of organic materials to cause spreading of the spray will increase the adherence, apparently owing in part at least to the more even distribution of the material over the leaf surface. Some investigators have found the use of certain inorganic salts or elements, particularly iron, greatly to increase the adherence of the spray material, while others have failed to obtain these results. 


\section{A NEW THEORY OF ADHERENCE}

A survey of the literature fails to show any definite theory or any attempt to explain why the adherence of one material to the leaf surface is superior to that of another. It appeared necessary as a point of departure to obtain some idea as to the causes of adherence between different substances. One of the best examples of adherence suggested was that existing between the particles of two oppositely charged colloids. If a colloid exhibiting a negative electric charge is added in .the proper proportions to one possessing a positive electric charge, the particles are attracted to each other, forming masses, which separate out as a precipitate. An example is the precipitation of a negative arsenious sulphide sol, a colloidal solution, by a positive ferric oxide sol. The colloidal particles of arsenious sulphide adhere strongly to those of ferric oxide. Suspensoids of dye substances also exhibit either positive or negative electric charges, and when two oppositely charged sols are mixed in the proper proportions, a precipitate is formed without any chemical reaction taking place. The question arises as to whether solids when not of colloidal dimensions possess such electric charges. Glass ground to colloidal dimensions exhibits a negative electric charge, and if added to a positive sol in the proper proportions will produce a precipitate. A glass beaker should therefore be negative if it possesses an electric charge. A positive sol placed in a clean glass container will have some of its colloidal particles deposited upon the glass and these adhere so thoroly that they can be removed only by acid. Another example is that of filter paper dipped into a positive sol such as methyl violet. It will be observed that altho the water rises on the filter paper the dye particles do not extend above the surface of the liquid. This is due to their precipitation on contact with the negative filter paper. The paper can be placed in running water and the dye particles will not be washed away. On the other hand, if the paper is placed in a negative indigo sol, the dye rises with the water far above the surface of the liquid and is readily removed by washing in running water.

King (I9I7), after a general review of all the theories of dyeing, reached the conclusion that the reaction between the fabric having one electric charge and a dye oppositely charged furnished the best explanation of the results obtained in the dye industry. The various negatively charged fabrics are easily dyed by positive dyes; but if a negative dye is to be used, the cloth must be rendered positive by means of a mordant. The mordant is positive and precipitates itself on the negative surface until a new surface with a positive charge is produced. The negative dye will then readily color the cloth. The mordant may be added to the dye in such quantity that the sol becomes positive, when it will give the desired results. 
If these electric forces are of sufficient magnitude to cause a dye to adhere to a fabric and withstand numerous washings, then if similar elertric charges exist on the leaf and the arsenical materials, they could be utilized to increase the adherence of the spray materials. The first question is, do the leaf and the common arsenical materials in use at present possess electric charges, and, if so, are they the same or opposite in character?

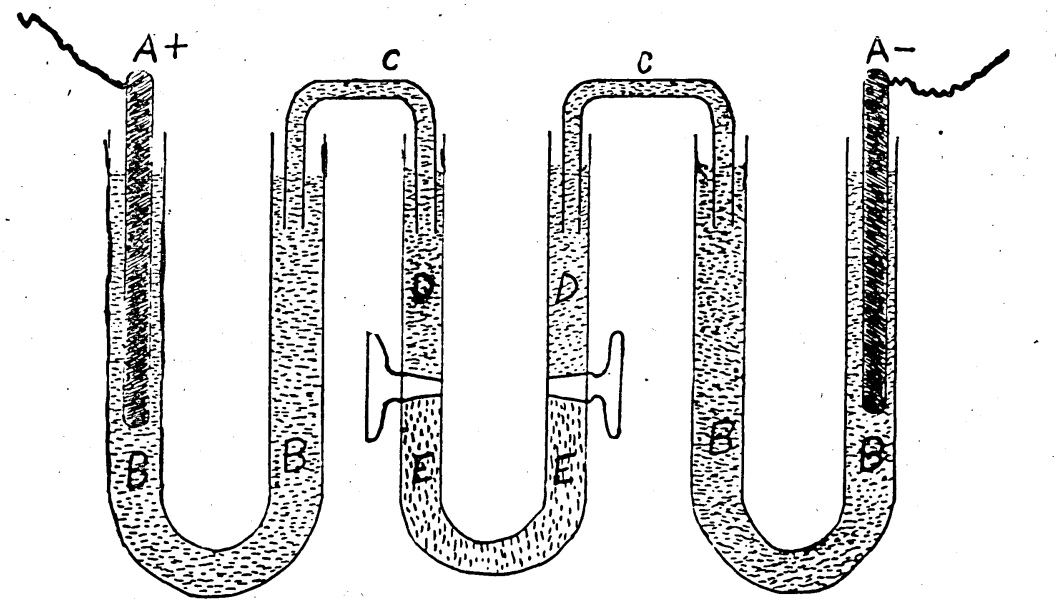

Apparatus Used in Determining the Migration of Particles in the Electric Field

A, electrodes; B, zinc sulphate solution; $C$ and $D$, tap water; $E$, suspension to be tested.

\section{ELECTRIC CHARGE EXHIBITED BY COMMON ARSENICAL PREPARATIONS}

Methods of testing the charge on the common arsenical preparations found on the market were considered. The first method taken up was the study of the precipitation of sols of known electric charge by suspensions of various arsenites and arsenates. This method, however, may give erroneous results, owing to chemical reactions between the various constituents or to the mutual adsorption of particles with like electric charges. The only method considered free from such objections is the determination of the migration of the particles in the electric field. Sols of the common arsenical materials were prepared by reducing the particles to colloidal dịmensions by grinding them with water in an agate mortar. A sol to be tested was placed in a U-tube as shown in the drawing. The stop cocks were closed and the upper end of each arm was washed out and filled with tap water. The tube was then clamped into position and connected with tubes of zinc sulphate, containing the electrodes, by means of small pieces of glass tubing filled with tap water. The level of the liquids was adjusted by connecting 
the zinc sulphate containers by means of another piece of tubing containing water. When the level had been established this piece of tubing was removed, the stop cocks were carefully opened, and the current was turned on. It was found possible to use a 220-volt direct current without the introduction of any resistance apparatus. Within half an hour the position of the suspensoid, indicated by its milky or opalescent appearance, was altered by the migration of the particles toward the oppositely charged electrode. Since all these materials carried negative charges, they migrated toward the positive electrode, the level of the suspensoid being raised in the positive arm of the tube and lowered in the negative arm. The rate of migration was faster on one side because of the pull of gravity on the particles, while the rate was retarded on the other side. In each case the position of the electrodes was changed and the direction of migration reversed. Lead arsenate, paris green, zinc arsenite, tri calcium arsenate, and magnesium arsenate were all found to be negative. The addition of calcium hydroxide did not alter the negative charge of calcium arsenate. Which arsenical substance possesses the strongest charge could not be determined by the experiment, since the rate of migration is governed not only by the magnitude of the charge but also by the size of the particles. The rain-proof colloidal preparation containing chromium and arsenic, previously mentioned, was tested, but no definite migration occurred even in two hours' time. This electric neutrality may be due to the presence of dextrin, which acts as a protective colloid.

\section{ELECTRIC CHARGE EXHIBITED BY THE LEAF SURFACE}

Having definitely proved by cataphoresis that the common arsenical preparations possess, when wet, an electric charge negative in character, the next question was the demonstration of an electric charge on the leaf surface. Empirically, the leaf should be negative, since filter paper made of cellulose is negative. Cotton, a plant product, is also negative. Stains, which give good results with leaf tissues, either are positive or are prepared with aluminum compounds so that the finished stain is positive. The epidermis of a plant stained with eosin, which is negatively charged, readily washes out in water; while Delafield's Haematoxylin; prepared so that it undoubtedly is positive, is not removed by washing. These statements, however, do not furnish positive proof of the negative character of the leaf. The possibility of determining the charge on the leaf by migration of its particles, after grinding in water, was discarded; because such a test would merely show that the cellulose and proteins of the leaf tissue are negative.

If gelatin in the form of a sol is placed in the electric field, the particles of gelatin migrate toward the electrode opposite in character to the charge carried by the gelatin particles. If a concentrated sol 
of gelatin is placed in the bottom of the U-tube and allowed to set to a gel, thus forming a semi-solid barrier, the passage of a current of electricity across the field will no longér be accompanied by a migration of gelatin particles. Under these conditions a flow of water will take place through the gelatin toward the pole with the same sign as the charge carried by the gelatin. The flow of water may be explained by the fact that when a solid takes on a certain electric charge, the water at its surface assumes the opposite sign. This phenomenon, known as electric endosmosis, is well known and is utilized in several industrial processes.

If water could be made to migrate across a leaf surface or through a leaf by endosmosis, it would give positive proof of the presence of an electric charge on the leaf surface. After several unsuccessful attempts the following method gave good results. A bean leaf was bound tightly over one end of a glass tube and the tube partially filled with water. It was then clamped into position with the leaf end immersed in a beaker of water. One electrode was inserted into the tube and the other was placed near the leaf in the beaker. When the current was turned on, the water passed through the leaf, moving in the direction of the negative electrode. Changing the position of the electrodes changes the movement of the water, about half a cubic centimeter passing through the leaf in half an hour. A few minute holes having been pricked in the upper epidermis of a citrus leaf, it was arranged in a similar manner, and the results obtained were even better, since more than a cubic centimeter of water was transferred in half an hour. The better results appeared to be due to the tougher texture of the citrus leaf, which made possible a tighter union with the tube. These experiments show that the leaf surface, when wet, exhibits a negative electric charge.

\section{PREPARATION OF AN ELECTRICALLY POSITIVE ARSENICAL SUBSTANCE}

Having shown that the arsenates and arsenites in use at the present time are electrically negative in character and that the leaf surface shows a similar negative charge, the question is presented as to how a positive material may be prepared. Most solids ionize in such a manner that they become negative, and of those which are positive and might be utilized in sprays, only three can be considered. ${ }^{5}$ Sols of aluminum, chromium, and iron oxides show the desired positive charge. Of these aluminum and iron appeared the most promising. Two methods of

5 Besides the three mentioned in this paper, positive arsenicals of lead, zinc, calcium, magnesium, copper, and barium have been made and a patent has been granted on these products. 
their utilization were suggested: (I) spraying the leaves wi:h the positive material, followed by the application of the negative arsenical material; and (2) the addition of sufficient positive material to the arsenical suspension to make the whole mixture positive in character. The first method is impractical, as it would require two sprayings of the plant. Aluminum hydroxide was precipitated by adding ammonium hydroxide to aluminum chloride, care being taken that not all of the chloride was converted into the hydroxide. A precipitate of aluminum hydroxide is readily peptized by aluminum chloride forming a positive sol. By filtering the precipitate, but not washing it, enough chloride remained to make the material electrically positive. In a preliminary test, a quantity of this aluminum hydroxide was mixed with lead arsenate and sprayed on young citrus trees in the greenhouse. To serve as a check, similar trees were sprayed with lead arsenate alone. After drying, some of the plants from each set were washed by a strong stream of water from a hose for five hours. A macroscopic examination showed practically none of the spray material on the leaves sprayed with the lead arsenate alone, while the leaves of those sprayed with the lead arsenate-aluminum hydroxide mixture were similar in appearance to the check plants which had not been washed. Similar results were obtained by addition of ferric hydroxide to lead arsenate. The substitution of geranium plants for citrus trees gave comparable results.

It would be difficult to make an estimate of the exact quantity necessary to give the desired results. The reactions taking place are more easily demonstrated by two colloids possessing opposite electric charges. An illustration would be the reaction of a negative sol of arsenious sulphide with a positive sol of ferric oxide. One particle of the ferric oxide carrying three positive charges would tend to neutralize the charges of three arsenious sulphide particles, since these carry only one negative charge. When a quantity of the ferric sol is added to an arsenious sulphide sol in such proportions that all the negative charges are not neutralized, no precipitation occurs and the mixture is negative. If the number of positive and negative charges is equal or nearly equal, the mixture produces electric neutrality and a precipitate is formed. If enough ferric oxide is added to produce an excess of positive charges, the mixture remains clear and is positive in character. This latter condition is the one sought when aluminum hydroxide or ferric hydroxide is added to lead arsenate to increase its adherence.

Owing to these difficulties, an effort was made to prepare an arsenical substance which would itself be positive. Grimaux (I884) showed that the precipitate formed when ferric chloride is added to sodium arsenate or sodium arsenite may be peptized, forming a sol which on dialysis gave a basic ferric arsenate, $\mathrm{Fe}_{2}\left(\mathrm{AsO}_{4}\right)$. Recently, Holmes 
and Rindfusz (I9II), Holmes and Arnold (I9I8), and Holmes and Fall (1919) have studied the preparation of ferric arsenate sols and gels. It is possible to prepare similar preparations of aluminum and chromium. In none of these papers is there any mention of the character of the electric charge carried by the particles of the ferric, aluminum, or chromium arsenate. Sols of ferric arsenate and arsenite, aluminum arsenate and arsenite, and chromium arsenate prepared in a similar manner.were found to be electrically positive. Ferric arsenate precipitated by adding 90 parts of a one-fifth molar solution of sodium arsenate to IOO parts of a one-fifth molar solution of ferric chloride was centrifuged, washed, and the paste dried. This material, ground to colloidal dimensions, showed a migration of the particles toward the negative poles, demonstrating that they carry a positive electric charge. Aluminum arsenate similarly prepared showed a slight migration toward the negative pole. These and several other arsenical materials were used in a field test of adherence.

\section{FIELD TESTS OF ADHERENCE}

The test of the adherence of different preparations was made on potato plants. The potatoes were in an open field exposed to wind, dew, and rain. During heavy showers, soil was splashed over the plants and washed off again, actually tending to scour the leaves. In the cultivation of the plants, soil was frequently thrown over the leaves, thus tending to remove the spray materials.

The following preparations were used in the proportions given, the amount of each material being figured on a dry basis.

TABILE I

Pounds to Gallons

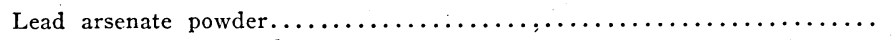

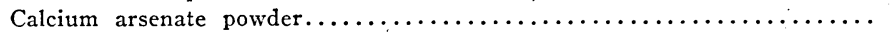

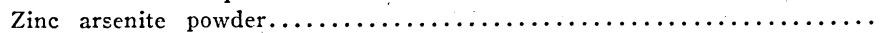

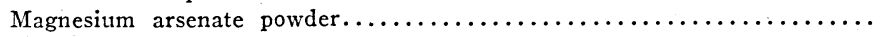

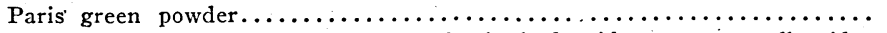

Lead arsenate powder, I.5 lbs. + ferric hydroxide paste, 0.4 lb. (dry

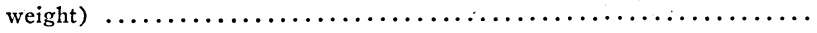

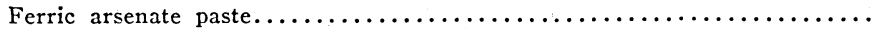

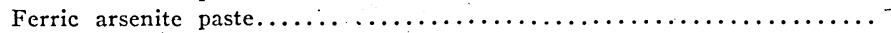

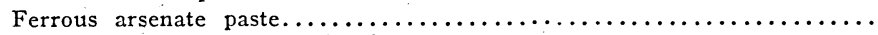

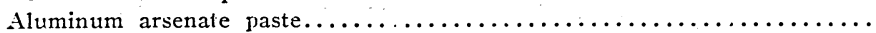

$\begin{array}{ll}1.5 & 50 \\ 1.5 & 50 \\ 1.5 & 50 \\ 1.5 & 50 \\ 1.5 & 50 \\ & \\ & 50 \\ 2.0 & 50 \\ 2.0 & 50 \\ 2.0 & 50 \\ 1.0 & 50\end{array}$

The materials were applied to one or two rows of potatoes and several rows throughout the plot were left unsprayed to serve as checks. When the sprayed plants were dry, ten representative leaves were collected from each set to be analyzed for arsenic. There was no rain for six days after the sprays were applied and then only o.o6 inch fell, hence all the compounds had an excellent opportunity to destroy the potato beetle larvae. Nine days after spraying the check plants were completely stripped of leaves and a count of larvae on the sprayed plants gave the results shown in Table II. 
TABLE II

Average

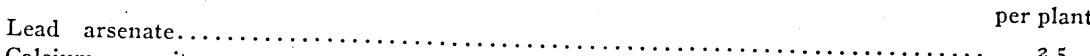

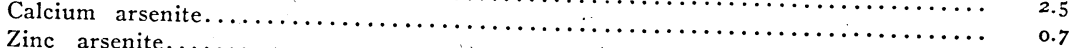

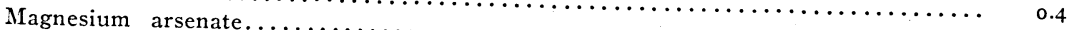

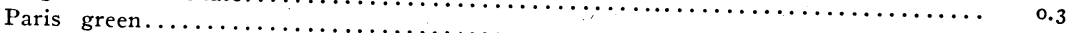

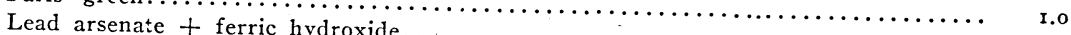

Ferric arsenate. . . . . . . . . .

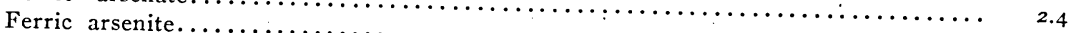

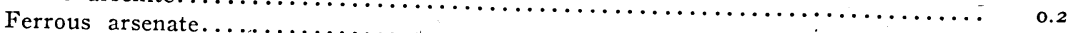

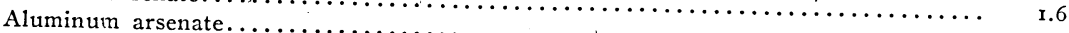

Some of these averages are high, owing to the proximity of check rows where the larvae, having stripped the plants, were migrating to adjacent rows. A count on part of the lead arsenate row next to a check row showed an average of four larvae per plant, while that part not adjoining the check row had an average of one larva per plant. This condition existed in the rows sprayed with ferric arsenate, ferrous arsenate, and aluminum arsenate, but not in the row treated with lead arsenate-ferric hydroxide mixture.

In the preparation of the lead arsenate-ferric hydroxide mixture there was a decided tendency for the particles to form masses which were extremely difficult to hold in suspension. The first six plants in the row obtained a very heavy dose of the spray materials while the rest of the row received very little. For this reason in the analysis of the plants, the first six plants in this set were kept separate from the others. In the analysis of the plant material for arsenic, the organic material was oxidized by boiling with nitric and sulphuric acids. The arsenic was determined by the Gutzeit method (Scott, I917). The leaves of the plants, taken immediately after the spray had dried, represented Ioo per cent of the spray material. Other determinations were made on leaves collected seven, eleven, and seventeen days after spraying, the average amount per leaf in terms of arsenious oxide being recorded in Table III. In this table is also given a record of the rainfall during this period.

Reviewing the field test, a relationship between the adherence and the electric charge is quite apparent. Lead arsenate, which adhered best of those possessing a negative electric charge, showed only 6.6 per cent at the close of the experiment. Aluminum arsenate tested in the electric field was only very slightly positive, since only a slight migration of the particles occurred. Ferrous arsenate was negative, but on the plant decomposition would produce ferric arsenate and ferric hydroxide according to Vermorel and Dantony. (1909). The decomposed material would then no doubt be positive. No definite data are available concerning the charge possessed by particles of the lead arsenate-ferric hydroxide mixture, but it was mixed in proportions 
which should form a positive material. Ferric arsenate was considered the most promising of the entire set, but its use requires further investigation.

TABLE III

\begin{tabular}{|c|c|c|c|c|c|c|c|c|c|c|c|}
\hline . & $\begin{array}{c}\text { After } \\
\text { spray- } \\
\text { ing }\end{array}$ & $\begin{array}{c}6 \\
\text { days }\end{array}$ & $\begin{array}{c}7 \\
\text { days }\end{array}$ & $\begin{array}{l}\text { Per } \\
\text { cent } \\
\text { of } \\
\text { total }\end{array}$ & $\begin{array}{l}\text { Io } \\
\text { days }\end{array}$ & $\begin{array}{c}\text { II } \\
\text { days }\end{array}$ & $\begin{array}{l}\text { Per } \\
\text { cent } \\
\text { of } \\
\text { total }\end{array}$ & $\begin{array}{l}\text { I6 } \\
\text { days }\end{array}$ & $\begin{array}{l}\text { I } 7 \\
\text { days }\end{array}$ & $\begin{array}{l}\text { Per } \\
\text { cent } \\
\text { of } \\
\text { total }\end{array}$ & $\begin{array}{c}\text { Total } \\
\text { rain- } \\
\text { fall }\end{array}$ \\
\hline Lead & $\begin{array}{c}\mathrm{Mg} . \\
0.75\end{array}$ & $\cdots$ & $\begin{array}{l}\text { Mg. } \\
0.10\end{array}$ & 40.0 & $\ldots$ & $\begin{array}{c}\mathrm{Mg} \text {. } \\
0.200\end{array}$ & 26.6 & $\cdots$ & $\begin{array}{l}\mathrm{Mg} . \\
0.050\end{array}$ & 6.6 & $\cdots$ \\
\hline Calcium arsen & 1.00 & $\cdots$ & 0.10 & 10.0 & $\cdots$ & 0.050 & 5.0 & $\cdots$ & 0.050 & 5.0 & $\cdots$ \\
\hline Zinc arsenite......... & 1.40 & $\cdots$ & 0.35 & 25.0 & $\cdots$ & 0.125 & 8.9 & ... & 0.075 & 5.35 & $\cdots$ \\
\hline Magnesium arsenate... & 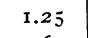 & $\cdots$ & 0.15 & 12.0 & $\cdots$ & 0.075 & 6.0 & $\cdots$ & 0.025 & 2.0 & $\cdots$ \\
\hline Paris green...$\cdots \ldots$ & 1.60 & $\cdots$ & o. Io & $6.2^{\circ}$ & $\cdots$ & 0.075 & 4.6 & $\cdots$ & 0.025 & 1.5 & $\cdots$ \\
\hline $\begin{array}{l}\text { Lead arsenate }+ \text { fer- } \\
\text { ric hydroxide }\end{array}$ & & & & & & & & & & & \\
\hline First 6 plants... & 8.00 & $\cdots$ & 2.40 & 30.0 & $\cdots$ & $\cdots$ & $\cdots$ & $\cdots$ & & $17 \cdot$ & $\cdots$ \\
\hline Other plants...... & 0.65 & $\cdots$ & 0.20 & 30.7 & $\cdots$ & 0.100 & I $5 \cdot 3$ & $\cdots$ & o & I 5. & $\cdots$ \\
\hline Ferric arsenate...... & 1.20 & $\cdots$ & 0.60 & 50.0 & $\cdots$ & 0.400 & $33 \cdot 3$ & $\cdots$ & oo & I 6. & $\cdots$ \\
\hline Ferric arsenite....... & 2.40 & $\cdots$ & 0.75 & 31.2 & $\cdots$ & 0.600 & 25.0 & $\cdots$ & 300 & $\mathrm{I} 2.5$ & $\cdots$ \\
\hline Ferrous arsenate..... & 2.80 & $\cdots$ & 1.25 & 44.6 & $\cdots$ & 0.750 & 26.7 & $\cdots$ & 0.350 & 12.5 & $\cdots$ \\
\hline Aluminum arsenate... & $\begin{array}{l}0.75 \\
\text { In. }\end{array}$ & $\cdots$ & $\begin{array}{l}\text { o.I } 5 \\
\text { In. }\end{array}$ & 20.0 & In. & 0.075 & 10.0 & In. & 0.075 & 10.0 & In. \\
\hline Rainfall & $\cdots$ & 0.06 & 0.03 & $\cdots$ & 0.80 & $\cdots$ & .. & $2.18^{*}$ & & & 3.0 \\
\hline
\end{tabular}

* This record represents one severe storm.

The poor adherence of calcium arsenate is of particular interest. Graham (I918) found it to adhere better than lead arsenate, while Wilson (1919) also considered it equal in adherence to lead arsenate. Graham's tests were conducted in the greenhouse and hard water was used to wash off the arsenical materials. Owing to the presence of the common calcium ion, the presence of calcium carbonate in the tap water would reduce the solubility and the rate of decomposition of the calcium arsenate. Wilson applied the calcium arsenate with lime and a similar effect was obtained. In these experiments, the calcium arsenate was used alone, and apparently rapidly dissolved, decomposed, and disappeared from the leaves.

\section{PREPARATION OF POSITIVELY CHARGED FERRIC ARSENATE}

In further investigations with ferric arsenate it was found that it did not always possess a positive electric charge, in fact it was often neutral or even negative. An effort was made to discover under what. conditions the best material could be prepared. Grimaux (I894) considered the first precipitate formed by the addition - of sodium arsenate to ferric chloride as represented by the formula $\left(\mathrm{AsO}_{4} \mathrm{H}\right)_{3} \mathrm{Fe}_{2}$. When this material was peptized by ferric chloride, a reaction was obtained represented by the following equation: 
$2\left(\mathrm{AsO}_{4} \mathrm{H}\right)_{3} \mathrm{Fe}_{2}+\mathrm{Fe}_{2} \mathrm{Cl}_{6}=3\left(\mathrm{AsO}_{4} \mathrm{H}\right)_{2} \mathrm{Fe}_{2} \mathrm{Cl}_{2}$

Upon dialyzing this sol a basic compound of ferric arsenate was retained by the membrane while hydrochloric acid passed through. Holmes and Arnold (I9I8) noted that the appearance of the gel obtained on dialysis depended upon the proportion of ferric chloride used in the peptization of the ferric arsenate precipitate. If a large quantity was used the gel obtained was reddish or reddish-brown, while if only a small quantity was used the gel was a dirty yellowish color. A study of these materials and the character of the charge carried by their particles should throw light upon the problem.

Three different sols were prepared, the first, which will be referred to as the 50-45, was made by adding slowly to 50 cubic centimeters of a one-fifth molar solution of ferric chloride, 45 cubic centimeters of a one-fifth molar solution of disodium arsenate, the precipitate being peptized as rapidly as it formed. The second was similarly prepared, but only 35 cubic centimeters of the arsenate was added, while 25 cubic centimeters was added to the third. These were known as the 50-35 and the 50-25 sols. The 50-45 sol was light yellow with greenish tints and somewhat clouded. The 50-35 and 50-25 sols were perfectly clear and of a deep yellow color with greenish tints. The three different sols were dialized in separate containers by means of collodion sacs. Only distilled water was used and all the wash water was saved for analysis. Having determined the amount of $\mathrm{Cl}, \mathrm{AsO}_{4}$, and $\mathrm{Fe}$ present in the original sols, a fairly accurate knowledge of the composition of the gel was obtained by the analysis of the wash water.

Hydrogen sulphide was first passed through the solution to remove the arsenic. This required considerable time to insure its complete removal. The arsenious sulphide was filtered off, redissolved, and the quantity of arsenic finally determined by iodine titration. The filtrate was made up to $\mathrm{I}, 000$ cubic centimeters and a portion used for the determination of the ferrous iron by titration with potassium permanganate. The chlorine was titrated with silver nitrate, using potassium chromate as an indicator. Considerable difficulty was experienced with this method since the indicator did not indicate the end point, more chlorine being found than had existed in the original sol. A double titration method using an excess of silver nitrate and then determining this excess by titration with ammonium thiocyanate using ferric sulphate as an indicator gave better results. The three different sols may be represented by the following equations based upon the results of the analyses. 


$$
\begin{aligned}
& \text { 50-25 Sol } \\
& 50 \quad \mathrm{FeCl}_{3}+25 \quad \mathrm{Na}_{2} \mathrm{H}\left(\mathrm{AsO}_{4}-\mathrm{XH}_{2} \mathrm{O}=\mathrm{Fe}-\mathrm{Fe}\left(\mathrm{AsO}_{4}\right) \quad \begin{array}{r}
\mathrm{Cl} \\
+\mathrm{Cl} \\
\mathrm{Cl}
\end{array}\right\} \mathrm{Fe}-\mathrm{Fe}\left(\mathrm{AsO}_{4}\right)+25 \mathrm{HCl}+50 \mathrm{NaCl} \\
& \mathrm{Fe} .=0.60256 \mathrm{~g} \text {. } \\
& \mathrm{AsO}_{4}=0.7006 \mathrm{~g} \text {. }
\end{aligned}
$$

50-35 Sol

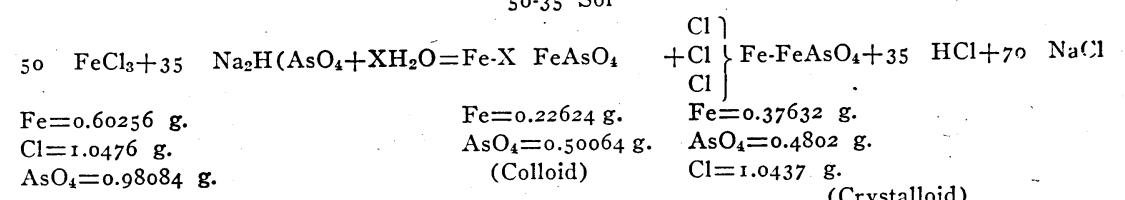

(Crystalloid)

$50-45$ Sol

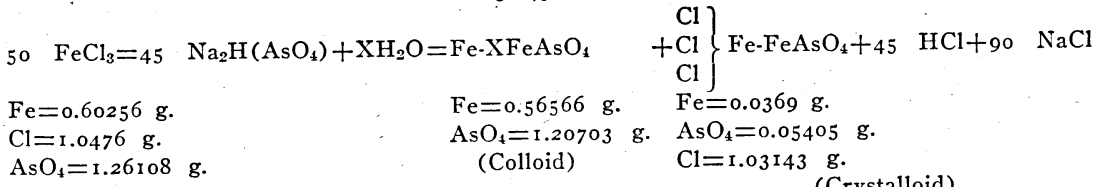
(Crystalloid)

From these equations it appears that there is a compound of ferric arsenate and ferric chloride formed which is capable of passing through a dialyzing membrane. ${ }^{6}$ The proportions in all three cases show that this compound is made up of one molecule of ferric chloride and one of ferric arsenate, $\mathrm{Cl}_{3} \mathrm{Fe} \cdot \mathrm{Fe} \cdot\left(\mathrm{AsO}_{4}\right)$. The proportions of ferric arsenate of iron in the colloid, however, vary. In the 50-25 it apparently may be represented by the formula $\mathrm{Fe} \cdot \mathrm{FeAsO}_{4}$, while in the other gels a larger quantity of ferric arsenate is present and the formula may be represented by $\mathrm{Fe} \mathrm{X} \mathrm{Fe}\left(\mathrm{AsO}_{4}\right)_{2}$. The 50-25 formula appears to be ferric oxide with an adsorbed molecule of ferric arsenate. The 50-35 and 50-45 may contain ferric oxide with an $\mathrm{X}$ number of adsorbed ferric arsenate molecules or it may consist of $\mathrm{Fe} \cdot \mathrm{FeAsO}_{4}$ with a number of unadsorbed ferric arsenate molecules. The 50-45 sol set to a gel when dialyzed from ten to fifteen hours, and was a rather opaque dirty yellow mass. The 50-35 and 50-25, after two to three days dialysis, finally formed a clear reddish gel.

The three gels were carefully dried, and after grinding to colloidal dimensions their migration in the electric field was determined. Both the 50-45 and the 50-35 migrated toward the positive pole and therefore - possessed a negative charge. The 50-25 sol, being positive, migrated toward the negative pole. All three sols before dialyzing had particles carrying positive charges.

- Arsenic acid may be liberated by the stronger hydrocloric acid, and the material which passes through the membrane may consist of a mixture of ferric cloride and arsenic acid. If such is the case, it is not apparent why this arsenic acid should be reduced in quantity by the addition of sodium arsenate. 
From these results it would appear that the pure or nearly pure ferric arsenate was negative, while if ferric chloride or ferric oxide is present with it, the particles possess a positive charge. Ferric arsenate prepared from equal molecular portions of disodium arsenate and ferric chloride was filtered, washed, dried, and prepared as a suspensoid by grinding. This material was negative. The addition of ferric chloride equal in weight to the ferric arsenate present in the suspensoid, caused it to take on a strong positive charge. Holmes and Fall (I9I9) have shown that the amount of ferric chloride, necessary to peptize a given quantity of ferric arsenate increases rapidly with the age of the precipitate up to one or two days, with only a smaller further increase being noted with older precipitates. This was found to be due to a decrease in the hydration of the precipitate and in the formation of larger aggregates with a consequent decrease in the external surface of the particles. In the present investigation it was found to be impossible to peptize with ferric chloride a precipitate which had been thoroly dried. However, as already shown, the ferric chioride is able to give the particles a positive charge, due apparently to a reaction with the surface of the particles. The amount necessary to give the desired results will vary with the surface area of the particles. The quantity necessary to produce a positive charge on the surface of large particles such as are present in the spray suspension, will be much less than is required where the surfaces are greatly increased by reducing the size of the particles to colloidal dimensions. The minimum quantity that may be used to give the desired adherence to a ferric arsenate spray, remains to be determined by further tests in later investigations.

Holmes and Rindfusz (I9I6) showed that ferric arsenate may be peptized by ammonium and other hydroxides, apparently a ferric oxide with an adsorbed arsenate being produced. This method has been tried and gives a positive material but is undesirable, since the presence of large quantities of ferric oxide reduces the toxicity of the mixture.

\section{COMPARATIVE TOXICITY OF DIF̈FERENT ARSENICAL PREPARATIONS}

Freshly precipitated ferric hydroxide is a well-known antidote for arsenical poisoning in higher animals (Sollmann, I917). The reaction between ferric hydroxide and arsenious oxide was first thought to be due to the formation of a basic ferric arsenate, but Biltz (1904) has shown that the ferric hydroxide adsorbs the arsenious oxide and does not form a definite compound. Vermorel and Dantony (I909) stated that ferrous arsenate on the plant was decomposed with the formation of ferric hydroxide. Scott and Siegler (I9I5) found ferrous arsenate - low in toxicity. In view of these facts it was considered advisable to 
obtain some idea of the toxicity of these new preparations in comparison with other common arsenical compounds.

\section{METHODS OF DETERMINING COMPARATIVE TOXICITY}

A short review of the literature dealing with toxicity presents several methods of obtaining a comparison of toxicity. Marlatt (1897) studied the toxicity of paris green, london purple, and copper arsenate, using as a basis of comparison the time required to kill the insects and the total number killed. Holloway (I912) attempted to express the toxicity numerically. Paris green at the rate of two milligrams per leaf was taken as a standard. The toxic value was expressed in the period of time required to kill. If a given poison required twice as long as paris green to produce death, then its toxic value would be expressed as 0.5 , while a poison killing more quickly than the standard would be represented by a number greater than I. This value was called the poison exponent. Mention is made of iron arsenate having a poison exponent for Heliothus obsoleta of 0.5 for the first instar, 0.33 + for the second, $0.8 \mathrm{I}$ for the third, and $0.47+$ for the fourth, fifth, and sixth instars. Scott and Siegler (1915) compared the killing values of various arsenical compounds by measuring in square inches the amount of leaf surface consumed by the fall webworm, Hyphantria cunea (Drury), feeding on black cherry, Prumus serotina. The time required to produce death was also taken into consideration. They consider lead arsenate as the best arsenical compound, but the triplumbic form is a slow acting poison. No attempt is made to arrange the preparations in the order of their toxicity and such an arrangement would be difficult, owing to the variation in quantity of the poisons used. Tartar and Wilson (1915) studied the comparative toxicity of lead hydrogen arsenate and basic lead arsenate. An arsenic analysis was made of the tissues of the dead insects, showing that those killed by the acid lead arsenate contained more arsenic. This was considered due to the more rapid adsorption of the chemically reactive diplumbic form, while the triplumbic lead arsenate was passed through the intestinal tract without much absorption taking place. Sanders and Brittain (1916) based their comparison of toxicity upon the percentage of larvae dead after feeding on sprayed foliage for a certain arbitrary number of days. Lovett and Robinson (1907), continuing the investi-gations started by Lovett and Wilson (I9I5), take into consideration the time required to kill, the approximate amount of the arsenical compound necessary to produce death, and the ratio of arsenic pentoxide in the tissues to that in the excrement. The ratio of lead hydrogen arsenate is given as $\mathrm{I}$ to 0.544 , calcium arsenate $\mathrm{I}$ to 0.70 , and basic lead arsenate I to $\mathrm{I} .5 \mathrm{I}$. 


\section{COMPARATIVE TESTS OF TOXICITY}

In the present work, locusts, Melanoplus femur-rubrum, were fed upon a standard mixture composed of I gram of bran to 0.5 gram of sugar, I. 5 cubic centimeters of water, and 0.04 gram of the poison to be tested. When the mixture became dry it was moistened with a few drops of water. Large glass cylinders covered with cheese-cloth at the top were used as feeding cages. Each cage contained ten insects. Numerous observations were made, and the number of dead locusts was recorded. When all were dead in any experiment their bodies and their excreta were separately collected, dried, and preserved for analysis. The experiments with each poison were repeated five times, hence the figures given represent the average for fifty locusts. The relative merit of the different methods of comparing toxicity may be judged from the data presented, which are based upon the time required to kill, the amount of bran mash consumed, and the ratio of the poison found in the body and in the excreta. The organic matter was destroyed by boiling with nitric and sulphuric acid and the arsenic determined by the Gutzeit method. (Scott I9I7). The data have been compiled in the following tables, where the materials are arranged in order of their toxicity, the most toxic substance being placed first.

These tables show clearly that the best basis of comparison is the ratio of the quantity of the chemical found in the body to that found in the excreta. This point is confirmed by feeding mixtures containing different quantities of the same chemical.

\section{TABLE IV}

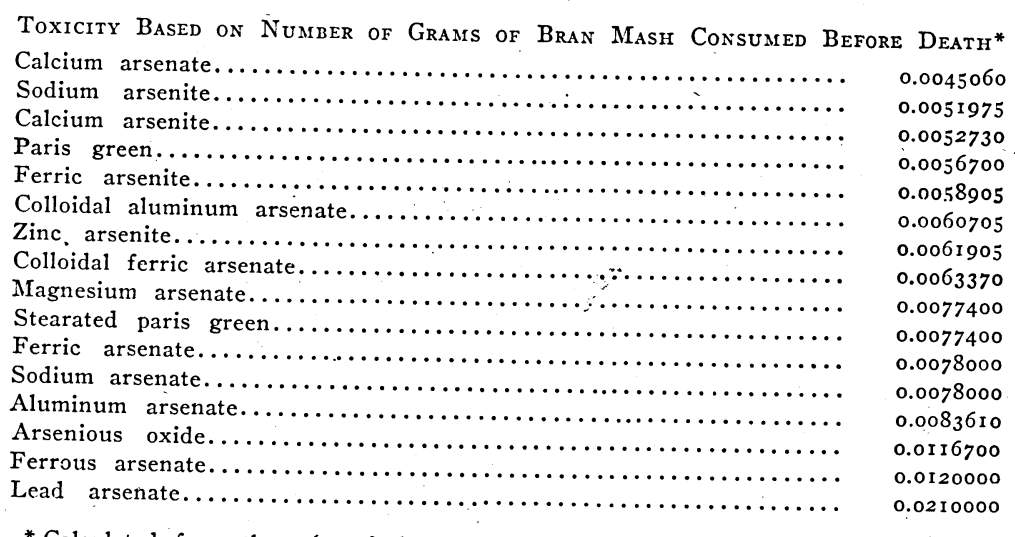

* Calculated from the stim of the arsenic recovered from the bodies and excreta and the proportion of arsenic present in the mash. 
TABLE V

Toxicity Based on the Average Number of Hours Necessary to Produce Death

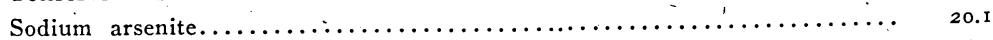

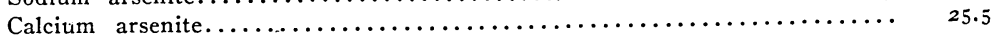

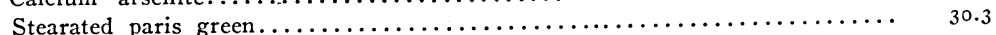

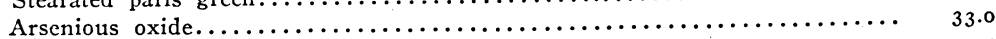

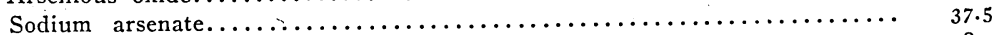

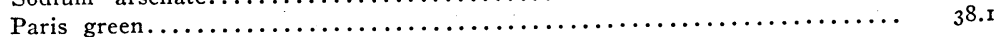

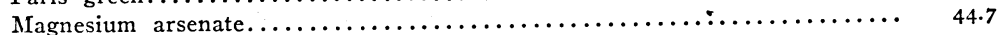

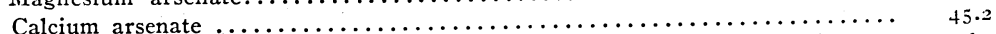

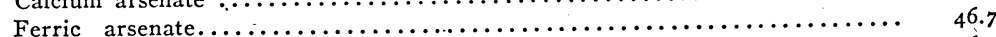

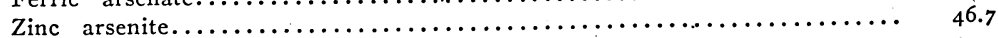

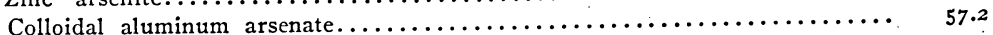

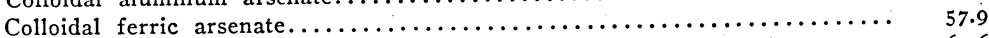

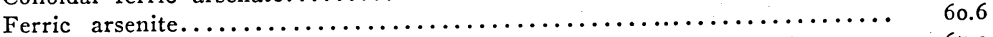

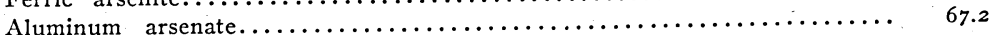

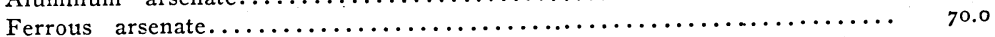

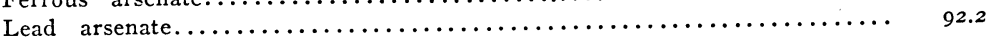

TABLE VI

Toxicity Based on the Ratio of the Chemical in the Body and in the Excreta

\begin{tabular}{|c|c|c|c|}
\hline \multirow[b]{2}{*}{ Chemical } & \multirow[b]{2}{*}{$\begin{array}{l}\text { Milligrams } \\
\text { in excreta }\end{array}$} & \multirow[b]{2}{*}{$\begin{array}{l}\text { Milligrams } \\
\text { in body }\end{array}$} & \multirow{2}{*}{ Ratio $\frac{\text { Excreta }}{\text { Body }}$} \\
\hline & & & \\
\hline Arsenious oxide................. & 0.005600 & 0.15000 & 0.037334 \\
\hline Sodium arsenite.$\ldots \ldots \ldots \ldots \ldots \ldots$ & 0.004330 & O.IIIIO & 0.039000 \\
\hline Colloidal aluminum arsenate........ & 0.006051 & 0.15130 & 0.039995 \\
\hline Sodium arsenate................ & 0.010000 & 0.25000 & 0.040000 \\
\hline Magnesium arsenate............... & 0.006400 & 0.16000 & 0.040000 \\
\hline Calcium arsenate................ & 0.005290 & 0.13200 & 0.040077 \\
\hline Colloidal ferric arsenate........... & 0.0 I I 440 & 0.21440 & 0.053360 \\
\hline Calcium arsenite................ & 0.006100 & 0.11000 & 0.055455 \\
\hline Stearated paris green............ & 0.010900 & 0.16000 & 0.068 I 30 \\
\hline 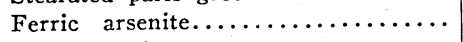 & 0.010578 & 0.13210 & 0.080077 \\
\hline 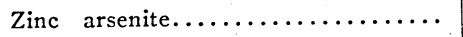 & 0.017800 & 0.13210 & 0.134750 \\
\hline Paris green $\ldots \ldots \ldots \ldots \ldots \ldots \ldots$ & 0.015000 & 0.11000 & 0.136370 \\
\hline 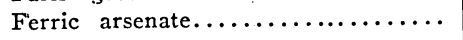 & 0.048000 & 0.16000 & 0.300000 \\
\hline 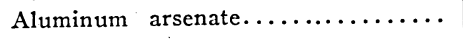 & 0.047160 & 0.13830 & 0.341240 \\
\hline 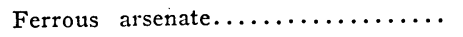 & 0.120000 & 0.20000 & 0.600000 \\
\hline 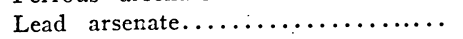 & 0.486660 & 0.44333 & 1.097700 \\
\hline
\end{tabular}

TABLE VII

\begin{tabular}{c|c|c|c}
\hline $\begin{array}{c}\text { Grams of lead } \\
\text { arsenate added to } \\
\text { bran mash }\end{array}$ & $\begin{array}{c}\text { Grams of bran } \\
\text { consumed before } \\
\text { death }\end{array}$ & $\begin{array}{c}\text { Hours required } \\
\text { kill }\end{array}$ & Ratio - Excreta \\
\hline 0.02 & 0.0300 & 66.5 & Body \\
0.04 & 0.0210 & 92.2 & 1.0000 \\
0.10 & 0.0108 & 69.5 & 1.0998 \\
0.20 & 0.0090 & 55.5 & 1.2005 \\
0.30 & 0.0070 & 58.0 & 1.2502 \\
& & 0.9092 \\
\hline
\end{tabular}

The hours required to produce death vary greatly while the quantity consumed is reduced rapidly. On the other hand, the results are affected but slightly by great differences in the quantity of the poison fed to the locusts. 


\section{A METHOD OF EXPRESSING TOXICITY}

Incidentally this method opens up a possibility of directly comparing arsenical compounds, giving them a definite numerical value in comparison with some standard compound of arsenic. In the present investigation, the object was merely to obtain an idea of the relative toxicity of certain new arsenical materials compared with those in use at the present time. By taking the reciprocal of the number obtained by dividing the quantity of the chemical in the excreta by that found in the body, the most toxic chemical becomes the one with the highest numerical value, as is shown in Table VIII.

TABLE VIII

\begin{tabular}{|c|c|c|}
\hline . & $\begin{array}{l}\text { Reciprocal } \\
\text { of the ratio }\end{array}$ & $\begin{array}{c}\text { Value when } \\
\text { lead arsenate }=I\end{array}$ \\
\hline 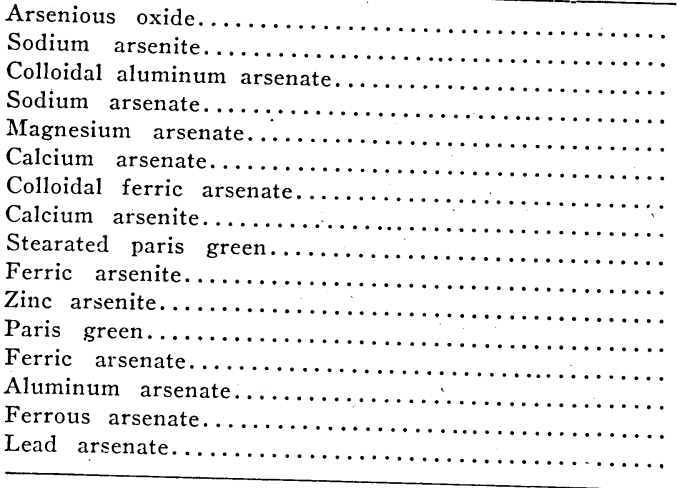 & $\begin{array}{l}26.78500 \\
25.64100 \\
25.00000 \\
25.00000 \\
25.00000 \\
24.95200 \\
18.74000 \\
18.03200 \\
14.78000 \\
12.48800 \\
7.42110 \\
7.33330 \\
3.33330 \\
2.93050 \\
1.66660 \\
0.91099\end{array}$ & $\begin{array}{l}29.4010 \\
28.1460 \\
27.4430 \\
27.4430 \\
27.4430 \\
27.3890 \\
20.5710 \\
19.7940 \\
16.1120 \\
13.7070 \\
8.1462 \\
8.0494 \\
3.6590 \\
3.2169 \\
1.8295 \\
1.0000\end{array}$ \\
\hline
\end{tabular}

Assuming the value of the lead arsenate to be I instead of 0.91099 it is simple to express the toxicity of any of the other arsenical compounds in terms of lead arsenate. Ferric arsenate would then have a value of 3.659 , or in other words, would be more than three times as toxic as lead arsenate, while paris green would be eight times; and arsenious oxide more than twenty-nine times as toxic as lead arsenate. Selecting absolutely pure lead arsenate as a standard, several common insects could be fed under definite conditions and a numerical value applied to any compound of arsenic placed on the market.

The values presented in this paper can not be used in this manner, as the lead arsenate used was a commercial product and not chemically pure.

\section{INFLUENCE OF FERRIC HYDROXIDE ON TOXICITY}

The results obtained by the addition of ferric hydroxide to arsenious oxide are recorded in Table IX. 


\begin{tabular}{|c|c|}
\hline TADLL $1 \mathrm{~A}$ & Ratio \\
\hline . & Chem. in body \\
\hline 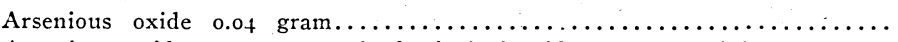 & 0.037334 \\
\hline 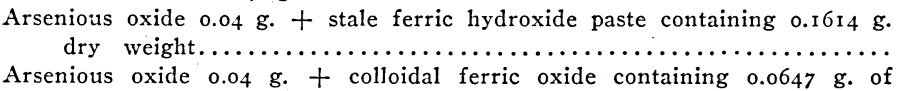 & 0.056000 \\
\hline 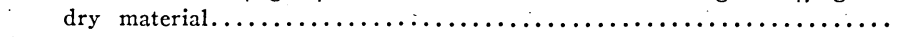 & 0.133333 \\
\hline Arsenious oxide $0.04 \mathrm{~g} .+$ fresh ferric hydroxide paste containing 0.1714 & $\cdot$ \\
\hline 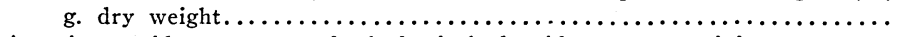 & 0.333333 \\
\hline $\begin{array}{l}\text { Arsenious oxide } 0.04 \mathrm{~g} \text {. } \pm \text { freșh ferric hydroxide paste containing o.I7I } \mathrm{g} \text {. } \\
\text { dry weight, but allowed to stand mixed for } 48 \text { hours before feeding... }\end{array}$ & 0.6 \\
\hline
\end{tabular}

The data show clearly that the addition of ferric hydroxide which adsorbs arsenious oxide reduces the toxicity of the mixture. Calcium hydroxide mixed in the same way gave a ratio of 0.05 compared with calcium arsenite with a ratio of 0.055455 . In this case the two reacted, giving calcium arsenite with -a ratio checking with the ratio of calcium arsenite previously tested. None of the figures given in the table check with ferric arsenite having a ratio of 0.080077 . This compound is apparently not formed.

The addition of ferric hydroxide to other arsenical compounds gave similar results. Sodium arsenate with a ratio of 0.039 was reduced by the addition of ferric hydroxide to o.I333, while paris green 0.13637 became 0.74834 .

These experiments explain the cause of the low toxicity of ferrous arsenate. Ferric arsenate is not so low in toxicity, but the addition of ferric hydroxide in any large quantity to increase the positive electric charge would no doubt reduce its toxicity. The adsorption of arsenic preparations by ferric hydroxide may be the explanation of the lack of injury to bean and peach foliage recorded by Scott and Siegler (1915). It has not been possible to investigate this phase of the subject at the present time.

\section{CONCLUSION REGARDING THE PHENOMENON OF ADHERENCE}

In that portion of the present investigation dealing with the adherence of spray materials to the leaf, it has been demonstrated that the leaf surface assumes, when wet, a negative electric charge and that suspensoids of the common arsenic compounds ionize in such a way that their particles are also negative. Based upon the results obtained in the dye industry, the assumption is made that spray materials carrying positive electric charges would adhere to the negatively charged leaf surface better than materials exhibiting negative charges. Field tests have confirmed this assumption. Positive arsenic preparations 
of different elements were prepared and tested, ferric arsenate being considered the most promising material. The presence of ferric hydroxide in the spray material is not desirable since, owing to its adsorption of arsenic, it lowers the toxicity of the preparation.

Many phases of the problem remain to be solved by future investigations. One of the most important questions is the successful combination of a positive ferric arsenate with a spreader to give the mixture both spreading and adherent properties. Organic materials which produce a film of the spray on the surface of waxy leaves should have no influence on the electric charge, but the protein type of spreader may have a decided effect. Since most emulsoids, șuch as gelatin, casein, and proteins, act as protective colloids, their addition to the spray might result in the complete loss of the electric charge. On the other hand. a mutual precipitation may occur (Bancroft, I920), or if the positive charges are in excess the material may retain its positive character. Only field tests will solve these problems. 


\section{LITERATURE CITED}

Arnal, A. Préparation des bouillies cupriques mouillantes et adhérents par l'addition de caséine. In Rev. Maladies des Plantes, v. 2, No. 2, p. 9-Io, I9I4. Abst. Rev. App. Ent. v. 2, ser. A, pt. 12, p. 681, I9I4.

Astruc, H. Bouillies mouillantes. In Prog. Agr. et Viticole, v. 59, No. 24, p. 746753 ; No. 25, p. 780-782. I913.

- Couvergne, A., and Mahoux, J. Sur 1' adhérence des bouillies insecticides à l' arseniate de plomb. In Compt. Rend. Acad. Sci. v. 152, p. I860-I862. I9I I.

Ballard, W. S. and Volck, W. H. Apple Powdery Mildew and Its Control in Pajaro Valley. U. S. Dept. of Agr. Bul. I20, I9I4.

Bancroft, W. D. Mutual Açtion of Sols. In Jour. Phys. Chem. v. 24, No. I, p. $2 \mathrm{I}-29 . \quad 1920$.

Biltz, W. Ueber die Einwirkung arseniger Säure auf "frisch gefälltes Eisenhydroxyd." In Berichte der Deut. Chem. Gesell. Ja. 37, v. 3, p. 3138-3150. I904.

Bourcart, E. Insecticides, Fungicides, and Weed-Killers. Scott, Greenwood and Son, London, I913. Translated by D. Grant.

Bradley, C. E. Commercial Fertilizers and Insecticides. Ore. Agr. Exp. Sta. Bul. 107. I910.

Cazeneuve, - . An Albuminous Bordeaux Mixture. In Vigne France, No. 4, p. 5I-53. I898. Cited from Exp.' Sta. Rec. v. Io, No. 5, p. $457 . \quad$ I898.

Chapaz, G. Les bouillies mouillantes. Bul. Agr. Algerie et Tunise, v. I9, p. I87191. I9I3.

Chappaz, G. Les bouillies mouillantes. In Prog. Agr. et Viticole, v. 59, No. I6, p. 487-49I. I913.

Cooper, W. F. and Nuttall, W. H. The Theory. of Wetting and the Determination of the Wetting Power of Dipping and Spraying Fluids Containing a Soap Basis. In Jour. Agr. Sci. v. 7, pt. 2, p. 219-239. I9I5.

Crouzet, E. Bouillie Lacto-cuprique. In La Messager Agricole v. 4, ser. Io, p. 306-307. I899.

Dalmasso, G. La lotta contro le Tignuole dell 'uva. In Stazioni sperimentali agrarie Italiane, v. 43, No. 7-9, p. 593-645. I910.

Del Guercio, G. I resultati delle prime esperienze tentate con i Polisolfuri colloidati contro la "Bianca-rossa" delgi Agrumi. In Rivista di Patologia Vegetale, v. 7 , No. 5, p. I29-I35. I9I4.

Edwardes-Ker, D. R. The Addition of Soft Soap to Lead Arsenate for Spraying Purposes. Jour. South East Agr. College (Wye, Kent). No. 22, p. 359-362. I913.

Fairchild, D: G. Experiments with Fungicides to.Prevent Leaf Blight of Nursery Stock. Jour. Mycol. v. 7, No. 4, p. 338-353. I894.

Fernald, C. H. A New Insecticide. Arsenate of Lead. Mass. Agr. Exp. Sta. (Hatch) Bul. 24, p. 3-7. I894.

Galloway, B. T. Report on Experiments Made in $189 \mathrm{I}$ in the Treatment of Plant Diseases. U. S. Dept. of Agr., Div. Veg. Path. Bul. 3, 76 pp. I89r. Field Work of the Year in Treating Plant Diseases. In Rept. U. S. Sec. of Agr. p. 216-234. I892. 
Some Observations on New and Old Insecticides and Their Combination with Fungicides. In Insect Life, v. 7, No. 2, p. I26-I32. I894.

Gastine, G. Sur 1' emploi des Saponines pour la préparation des émulsions insecticides et des liqueurs de traitements insecticides et anticryptogamiques. Compt. Rend. Acad. Sci., v. I52, p. 532-534. I9II.

. Le Progrès agricole et viticole, v. 33, No. I4, p. 427-429. I9II.

Gillette, C. P. Experiments with Arsenites. Iowa Agr. Exp. Sta. Bul. Io, p. 40I-420. I890.

Girard, Aime. Recherches sur 1' adhérence aux feuilles des plantes, et notamment auz feuilles de la pomme de terre, des composés cuivriques destinés à combattre leurs maladies. In Comp. Rend. Acad. Sci., v. II4, No. 5, p. 234-236. I892.

Graham, S. A. Potato Spraying in Minnesota. In I7th Rept. State Ent. of Minn. p. 2I-3I. I9I8.

Gray, G. P. Wettable Sulfurs. In Monthly Bul. St. Comm. of Hort. Calif., v. 7, No. 4, p. I9I-I92. I9I3.

Grimaux, E. Sur des sels ferriques colloidaux. Compt. Rend. Acad. Sci., v. 98, No. 25, p. I540-I542. I 884.

Guillon, G. M. and Gouirand, G. Sur l'adhérence des bouillies cupriques utilisées pour combattre les maladies cryptogamiques de la Vigne. Compt. Rend. Acad. Sci., v. 127, No. 4, p. 254-256; No. II, p. 423-424. 1918.

Harkins, W. D. and Brown, F. E. The Determination of Surface Tension (Free Surface Energy), and the Weight of Falling Drops: The Surface Tension of Water and Benzene by the Capillary Height Method. Jour. Amer. Chem. Soc., v. 4I, No. 4, p. 499-524. 1918.

Harkins, W. D., Brown, F. E., and Davies, E. C. H. The Structure of the Surfaces of Liquids, and Solubility as Related to the Work Done by the Attraction of Two Liquid Surfaces as They Approach Each Other. Jour. Amer. Chem. Soc., v. 39, No. 3, p. 354-364. I917.

Harkins, W. D., Davies, E. C. H., and Clark, G. L. The Orientation of Molecules in the Surface of Liquids, the Energy Relations at Surfaces, Solubility, Adsorption, Emulsification, Molecular Association, and the Effect of Acids and Bases on Interfacial Tension. In Jour. Amer. Chem. Soc., v. 39, No. 4, p. 54I-596. II9I7.

Hartzell, F. Z. The Influence of Molasses on the Adhesiveness of Arsenate of Lead. In Jour. Econ. Ent., v. II, No. I, p. 62-66. I9I8.

High, M. M. Cactus Solution as an Adhesive in Arsenical Sprays for Insects. U. S. Dept. of Agr. Bul. I60. I915.

Holloway, T. E. The Poison Exponent: A Symbol of the Toxicity' of 'Chemicals in Their Relation to Insects. In Jour. Econ. Ent., v. 5, No. 6, p. 452-456. I9I2.

Holmes, H. N., and Arnold, R. The Peptization of Ferric Arsenate and Phosphate and the Formation of Their Gels. In Jour. Amer. Chem. Soc., v. 40, No. 7, p. I0I4-IoI9. I9I8.

, and Fall, P. H. The Influence of the Age of Ferric Arsenate on Its Peptization. In Jour. Amer. Chem. Soc., v. 4I, No. 5, p. 713-717. I9I9.

, and Rindfusz, R. E. The Colloidal Arsenates and Phosphates of Iron. In Jour. Amer. Chem. Soc., v. 38, No. I0, p. I970-I982. 1916.

Howe, R. G. Results of Spraying Experiments, 1909. I11. Agr. Exp. Sta. Circ. I37. I910. 
Issleib, - . Die Beseitigung der Insekten, welche den Wein- und Obstbau schädigen, durch Verklebung mit Hilfe von Moosschleim. In Zeitschr. für Pflanzenkrankheiten, v. 24, pt. 2, p. 78-79. I9I4.

Jacobson, C. A. Alfalfa Saponin. Alfalfa Investigation VII. In Jour. Amer. Chem. Soc., v. 4I, No. 4, p. 640-648. I9I9.

Jones, P. R. Machine Gun Work with a New Formula on Red Spider in Tulare County. In Monthly Bul. St. Comm. Hort., Calif., v. 7, No. 7, p. 455-457. I9I3.

Kilgore, B. W. On the Cause and Prevention of the Injury to Foliage by Arsenites Together with a New and Cheap Arsenite and Experiments on Combining Arsenites with Some Fungicides. N. C. Agr. Exp. Sta. Bul. 77b, Tech. Bul. No. 2. I89I.

King, P. E. General Review and Bibliography of Dyeing. Ist Rept. on Colloidal Chem. and Its Indust. App., British Assoc. Adv. Sci., p. 20-38. I9I7.

Kirkland, A. H. On the Value of Glucose in Spraying. In Mass. St. Bd. of Agr. 46th Ann. Rept., p. 478-48I. I898.

Lafforgue, G. Les bouillies cupriques mouillantes. In La vie Agricole, v. 3, p. 6II-6I4. I9I3.

Langmuir, I. The Constitution and Fundamental Properties of Solids and Liquids. II Liquids. In Jour. Amer. Chem. Soc., v. 39, No. 9, p. I848-I906. I9I7.

Lavergne, G. Rapport sur le black-rot dans l'Armagnac en 1895. In Bul. Min. Agr., France,-v. 15, No. 2, p. 285-291. I896.

Lees, A. H. Winter Cover Washes. In Ann. App. Biol., v. I, No. 3-4, p. 35I364. 1915. 249. 1916.

. Accessory Wetting Substances with Special Reference to Paraffin Emulsions. In Ann. App. Biol., v. 3, No. 4, p. I4I-I49. I9i7.

Lefroy, Maxwell H. The Psylla Disease of Indigo in Behar. In Agr. Jour. India, v. 8, pt. I, p. I-26. I9I3.

Lovett, A. L. Spreaders for Arsenate Sprays. In Jour. Econ. Ent., v. II, No. I, p. 66-69. I9I8.

Insecticide Investigations. Ore. Agr. Exp. Sta. Bul. I69. I920. and Robinson, R. H. Toxic Values. and Killing Efficiency of the Arsenates. In Jour. Agr. Res., v. Io, No. 4, p. 199-207. I9I7.

Lowe, V. H. Combating the Cottonwood Leaf Beetle. In N. Y. Agr. Exp. Sta. I5th Ann. Rept. p. 543-544. I896.

Mausier, - . Principles d'après lesquels doivent être composés les insecticides. In Bul. Soc. des Agr., France, v. 6்̇, p. 86-93. 1908.

Marlett, C. L. Comparative Tests with New and Old Arsenicals on Foliage and with Larvae. U. S. Dept. of Agr. Div. of Ent. Bul. 6, new series, p. 30-35. I897.

Melander, A. L. The Control of the Codling Moth. Wash. St. Coll. of Agr. Bul. I03, p. 4-55. I9II.

Millardet and Davis. Résultats de divers procédés de traitement sur le developpement du mildiou. In Jour. Agr. Pratique, v. 2, No. 50, p. 76I-770. 1886. 
Neüls, J. D. The Use of Flour Paste in Lime Sulphur Solutions in the Control of the Citrus Red Spider. In Monthly Bul. St. Comm. Hort. Calif., v. 2, No. 6, p. 557 . I9I3.

O'Kane, W. C., Hadley, C. H., and Osgood, W. A. Arsenical Residues after Spraying. N. H. Agr. Exp. Sta. Bul. I83. I917.

Parker, J. R. The Use of Soap to Retard the Settling of Certain Arsenicals. Mont. Agr. Exp. Sta. Bul. 86, p. 35-45. I9II.

Parker, Wm. B. Flour Paste as a Control for Red Spiders and as a Spreader for Contact Insecticides. U. S. Dept. of Agr. Bur. of Ent. Circ. I66. I9I3.

Perraud, Joseph. Recerches sur quelques moyens permettant d'augmenter l'adhérence des bouillies cupriques. In Comp. Rend. Acad. Sci. v. 127, No. 22, p. 876-879. I898.

- Sur une nouvelle bouillie cuprique, plus spécialement destinée à combattre le black rot. In Compt Rend Acad. Sci., v. I27, No. 23, p. 978-980.

Pickering, S. U. The Interaction of Metallic Sulphates and Caustic Alkalies. In Jour. Chem. Soc., v. 91.92, p. I98I-I988. 1907.

Quincke, G. Ueber den Randwinkel und die Ausbreitung von Flüssigkeiten auf festen Körpern. In Wiedemann's Annalen der Physik und Chemie, neue Folge, Band II, No. Io, p. I45-194. 1877.

Rapport au Ministre de L'Agriculture. Sur le traitement du mildiou dans lè médoc. In Jour. Agr. Pratique, v. 2, No. 49, p. 659-662. I885.

Ravaz, L., and Bonnet, A. Expériences sur le traitement du mildiou. In Ann. de l'Ecole Nationale d'Agri. de Montpellier, n. ser., v. 3, No. 2, p. I57-I68. I903.

Robak, F. Wild Volatile-Oil Plants and Their Economic Importance. I Black Sage; II Wild Sage; III Swamp Bay. U. S. Dept. of Agr. Bur. Plant Indust. Bul. 235. I9I2.

Sanders, G. E., and Brittain, W. H. The Toxic Value of Some Common Poisons Alone and in Combination with Fungicides, on a Few Species of Biting Insects. In Proc. Ent. Soc. Nova Scotia, No. 2, p. 55-64. 1916.

Scott, E. W., and Siegler, E. H. Miscellaneous Insecticide Investigations. U. S. Dept. of Agr. Bul. 278. I9I5.

Scott, W. W. Standard Methods of Chemical Analysis. Van Nostrand Co., N. Y. I9I7.

Selby, A. D. Spraying for Apple Scab in 1908. In Ohio Agr. Exp. Sta. Circ. 87, p. 4-8. I908.

Sirrine, F. A. A Spraying Mixture for Cauliflower and Cabbage Worms. N. Y. Agr. Exp. Sta. (Geneva) Bul. I44. I898.

Smith, John B. Insecticides. Rept. of Ent. In 28th Ann. Rept. N. J. Agr. Exp. Sta., p. 359-373. I9I0.

Sta. p. 359-373. I9ro.

Smith, Loren B. Relationship Between the Wetting Power and Efficiency of Nicotine-Sulphate and Fish-oil Soap Sprays. In Jour. Agr. Res., v. 7, No. 9, p. 389-399. 1916.

Sollmann, T. A Manual of Pharmacology, I9i7. 
Stearns, L. A. Experiments on the Control of the Oriental Fruit Moth. In Quart. Bul. Va. St. Crop Pest. Comm, v. 2, No. I. 1920.

Stewart, V. B. Some Important Leaf Diseases of Nursery Stock. Cornell ,Agr. Exp. Sta. Bul. 358, p. I67-226. I915.

Surface, H. A. Calendar for 1905 for Treating Insect Pests and Plant Diseases. Monthly Bul. Div. Zoöl. Pa. v. 3, No. I, p. 8-30. 1905.

Swingle, W. T. An Improved Method of Making Bordeaux Mixture. In Jour. Mycol., v. 7, No. 4, p. 365-37r. I894.

Tartar, H. V. and Bundy, L. A. Arsenic Soluble in Mixtures of Lead Arsenate and Soap. In Jour. Indust. and Engin. Chem., v. 5, No. 7, p. 561-562. 1913. and Wilson, H. F. The Toxic Value of the Arsenates of Lead. In Jour. Econ. Ent., v. 8, No. 5, p. 48I-486. I915.

U. S. Patent No. I166387. Dec. 28, 1915.

Van Slyke, L. L., and Urner, F. A. The Composition of Commercial Soaps in Relation to Spraying. N. Y. Agr. Exp. Sta. (Geneva) Bul. 257. I904.

Vermorel, V., and Dantony, E. De l'emploi de l'arséniate ferreux contre les insects parasites des plantes. Compt. Rend. Acad. Sci., v. I48, No. 5, p. 302304. 1909.

- Arséniate ferreux et bouillies cupriques. In Progres Agricole, v. 5I, p. 423-424. I909.

- Des principes généraux que doivent présider à l'établissement des formules insecticides. In Compt. Rend. Acad. Sci., v. I5I, p. II44-II46. I9I0.

Acad. Sci., v. 152, p. 972-974. I911.

. Bouillie anticryptogamique au savon de cuivre colloidal. In Compt. Rend. Acad. Sci., v. 152, p. I263-1265. 1911 .

- Tension superficielle et pouvoir mouillant des insecticides et fongicides. Moyen de rendre mouillantes toutes les bouillies cupriques ou insecticides. In Comp. Rend. Acad. Sci., v. I54, No. 20, p. I300-I302. I9I2.

. Preparation des bouillies alcalines mouillantes. In Prog. Agr. et Viticole, v. 59, No. 24, p. 745-746. I913.

Viticole, v. 59, No. 25, p. 778-780. 1913. v 63, p. 509. 1915.

Volck, W. H. Sulphur Sprays for Red Spider. Cal. Agr. Exp. Sta. Bul. I54. I903.

The Apple Powdery Mildew in Pajaro Valley. Office of County Ent. for Monterey and Santa Cruz Counties, Cal. Special Bul. I, Igog.

Waite, M. B. Experiments on the Apple with Some New and Little-known Fungicides. U. S. Dept. of Agr. Bur. P1. Indus. Circ. 58. 1910.

Washburn, F. L. Practical Work with the Codling Moth and with a Combined Insecticide and, Fungicide. Ore. Agr. Exp. Sta. Bul. Io. I89I.

Weinmann, J. Bouillies mouillantes. In Progrès Agricole, v. 57, p. 709-712. 1912.

Willows, R. S. and Hatschek, E. Surface Tension and Surface Energy and Their Influence on Chemical Phenomena. J. and A. Churchill, London. I9I5.

Wilson, H. F. Common Insecticides. Wis. Agr. Exp. Sta. Bul. 303. I9I9. 


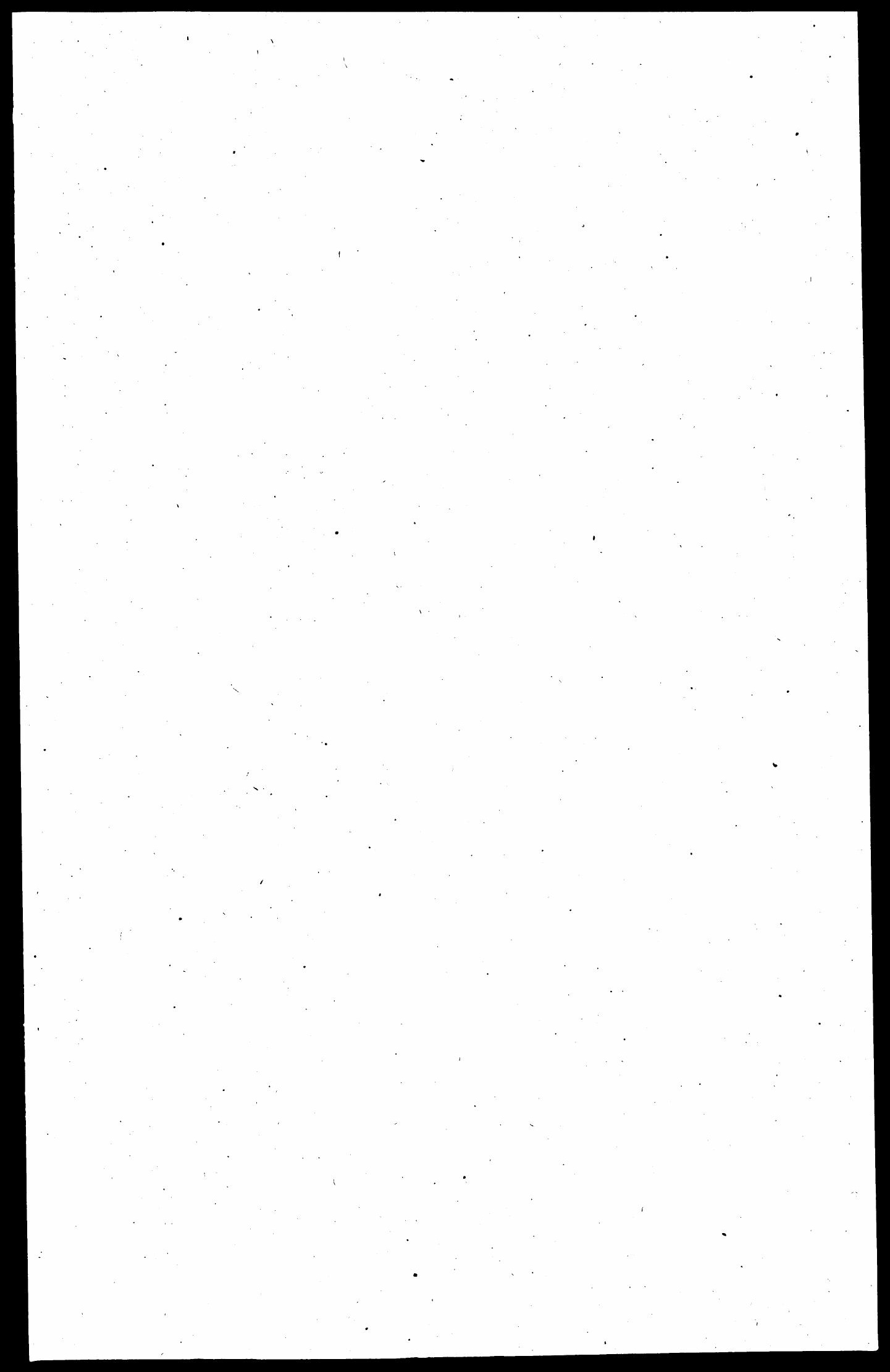




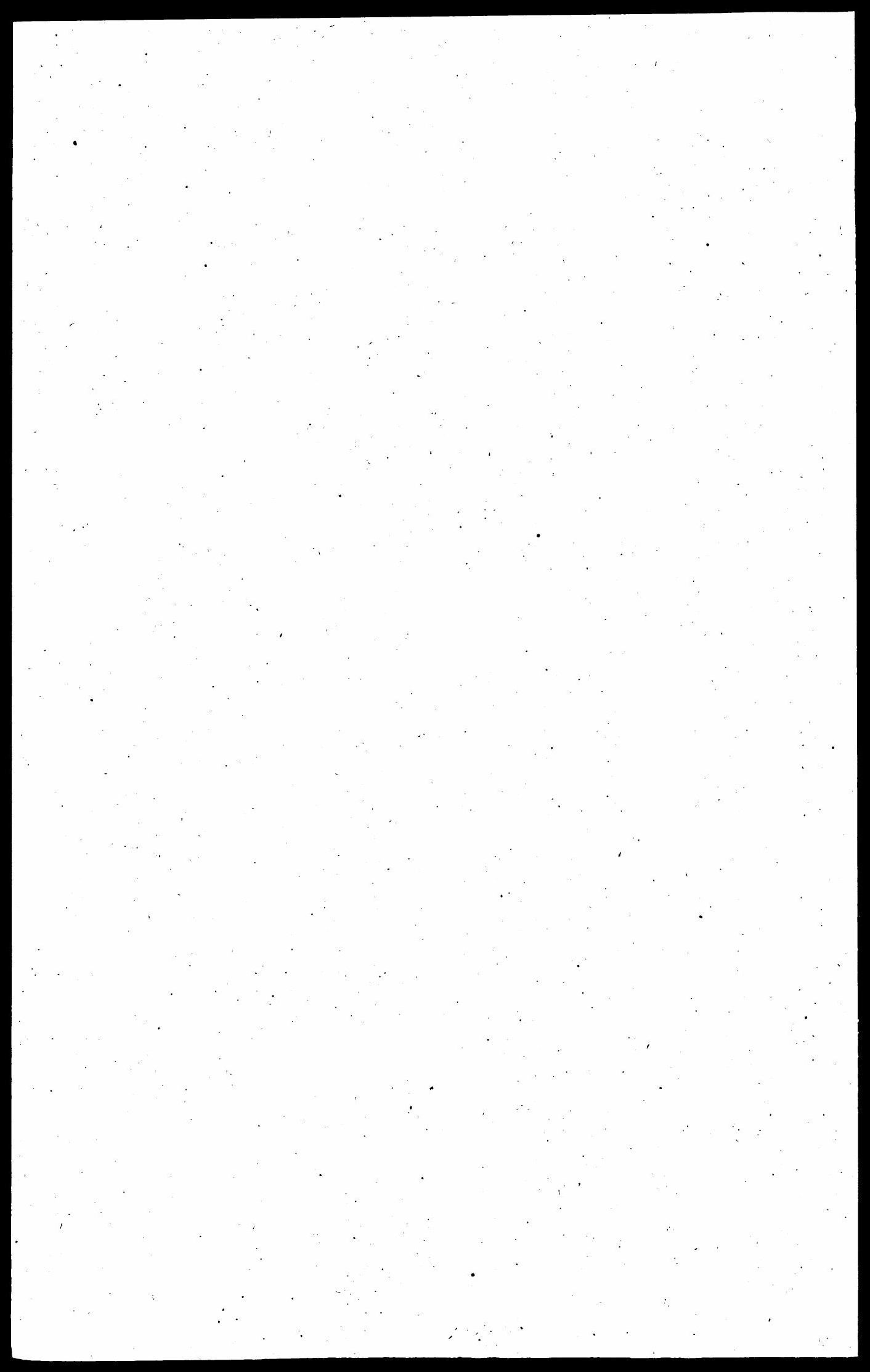


